A N N A LES

UN I VERSITATIS M A R I A E C URIE-SKŁODOWSK A
LUBLIN - POLONIA
VOL. XII, 2
SECTIOL

Instytut Muzyki Uniwersytetu Marii Curie-Skłodowskiej

WOJCIECH BERNATOWICZ

\title{
Musical Evita Andrew Lloyda Webbera na tle wybranych gatunków muzyki scenicznej XIX i XX wieku* \\ Andrew Lloyd Webber's Musical Evita in the Context of Selected Genres of Nineteenth and Twentieth-Century Stage Music
}

Analiza musicalu jest dość trudnym wyzwaniem badawczym głównie ze względu na brak opracowań naukowych, które przynosiłyby wyczerpujące ujęcia przedmiotu i dostarczały wzorców dla ujęć muzykologicznych. W literaturze światowej, zwłaszcza angielsko- i niemieckojęzycznej, znajdujemy wprawdzie liczne prace poświęcone twórczości musicalowej ${ }^{1}$, ale - jak się wydaje - nie wypracowano w nich dotąd takich kanonów metodologicznych i terminologicznych, które tworzyłyby pewny, ugruntowany już tradycją punkt oparcia dla badań analitycznych. W Polsce szerzej zakrojone studia nad formą musicalu prowadził Marek Bielacki. Jego syntetyczna

* Artykuł jest zmodyfikowanym fragmentem mojej pracy magisterskiej. W. Bernatowicz, Musicale Andrew Lloyda Webbera ze szczególnym uwzględnieniem Evity w kontekście wybranych gatunków twórczości scenicznej XIX i XX wieku, praca magisterska, promotor dr hab. Iwona Lindstedt, Instytut Muzykologii Wydziału Historycznego Uniwersytetu Warszawskiego 2014, ss. 123.

${ }^{1}$ Zob. m.in.: G. Bordman, American Musical Theatre. A Chronicle, Nowy Jork 1978; J. Kenrick, Musical Theatre. A History, Nowy Jork 2008; The Cambridge Companion To Musical, red. W. A. Everett, P. R. Laird, Cambridge 2008; J. B. Jones, Our Musical, Ourselves, Nowa Anglia 2003; M. Taylor; M. A. Bauch, Selbstrefl exivität im amerikanischen Musical, Kolonia, 2013; idem, Europäische Einflüsse im amerikanischen Musical, Marburg, 2013; M. Taylor, D. Symonds, Studiyng Musical Theatre, Londyn 2014. 
praca Musical. Geneza i rozwój formy dramatyczno-muzycznej koncentruje się wokół historycznego aspektu rozwoju formy musicalu, zasadniczo jednak dystansuje się od opisu i szczegółowej analizy elementów dzieła muzycznego, wewnętrznej struktury formalnej, rozwiązań instrumentacyjnych czy fakturalnych.

Przedstawiona w niniejszym artykule analiza musicalu Evita Andrew Lloyda Webbera $^{3}$ nie rości sobie bynajmniej prawa do ustanowienia metodologicznych podstaw naukowego ujęcia zjawiska musicalu. Jako jedynie muzykologiczny przyczynek do badań nad twórczością Webbera ${ }^{4}$ jest przede wszystkim próbą przybliżenia utworu w jego możliwie pełnym kształcie słowno-muzycznym, z uwypukleniem najważniejszych dlań elementów, przy jednoczesnym uwzględnieniu szerszego kontekstu muzyki scenicznej XIX i XX wieku.

$\mathrm{Na}$ omówienie dzieła złożą się cztery zasadnicze partie tekstu, w których przedstawione zostaną kolejno: treść libretta, architektonika kompozycji, zabiegi stylizacyjne i archaizacyjne, zastosowane $\mathrm{w}$ utworze motywy przypominające. W poszczególnych fazach analizy muzycznej zwrócimy uwagę na najważniejsze i najbardziej charakterystyczne zjawiska w zakresie melodyki, harmoniki i rytmiki, obok tego - na rozmaite rozwiązania formalne, sposoby kształtowania warstwy ekspresyjnej dzieła oraz wzajemne powiązania libretta z muzyką. Na wszystkich etapach wywodu obserwacjom analitycznym towarzyszyć będą odniesienia do twórczości scenicznej XIX-XX stulecia, w których postaramy się porównać cechy Evity z charakterystycznymi właściwościami XIX-wiecznych oper i operetek oraz

${ }^{2}$ M. Bielacki, Musical. Geneza i rozwój formy dramatyczno-muzycznej, Łódź 1994. Zob. też prace innych polskich autorów dotyczących problematyki musicalowej, m.in.: M. Gołębiowski, Musical amerykański na tle kultury popularnej USA, Warszawa 1989; A. Marianowicz, Przetańczyć cała noc... Z dziejów musicalu, Warszawa 1979; M. Karpiński, Życie i śmierć na Broadwayu: szkice o współczesnym teatrze amerykańskim, Warszawa 1990; D. Skotarczak, Od Astaire'a do Travolty. Amerykański musical filmowy w kontekście historii Stanów Zjednoczonych, Poznań 2000; idem, Historia amerykańskiego musicalu filmowego, Wrocław 2002.

${ }^{3} \mathrm{Na}$ temat Evity pisali m.in.: S. Miller, Inside Evita, http://www.newlinetheatre.com/evitachapter. html [data dostępu: 07.05.2015] (autor przedstawia historię powstania musicalu, analizuje wewnętrzną strukturę tekstu, relacje pomiędzy bohaterami pierwszoplanowymi, ukazuje dzieło w kontekście sytuacji społecznej w Argentynie drugiej poł. XX wieku, do analizy scen wprowadza kategorię leitmotivu); J. Richstad, Ch-Ch-Changes: A World in Flux, [w:] Music Resource, red. T. Asnes, Nowy Jork 2012, https://scholarscup.wikispaces.com/file/view/Music+Resource.pdf [data dostępu: 07.05.2015] (autorka analizuje dzieło pod kątem historycznym, dokonuje porównania wersji scenicznej i filmowej dzieła).

${ }^{4}$ O Andrew Lloyd Webberze i jego twórczości musicalowej zob. m.in.: M. Walsh, Andrew Lloyd Webber: His Life and Works, Nowy Jork 1989; S. Citron, Stephen Sondheim and Andrew Lloyd Webber, Oksford 2001; M. Coveney, The Andrew Lloyd Webber Story, Londyn 2000; K. Richmond, Andrew Lloyd Webber: His Life and Works, Londyn 2000; S. Citron, Stephen Sondheim and Andrew Lloyd Webber, Oksford 2001; J. Snelson, Andrew Lloyd Webber, New Haven - Londyn 2004; K. Marsico, How to Analyze Andrew Lloyd Webber, Minneapolis 2011. 
XX-wiecznych musicali; po to, aby dzieło Webbera ukazać na szerszym tle gatunkowym, głębiej też i bardziej wielostronnie je zinterpretować.

Przypomnijmy, że musical Evita - skomponowany do libretta Tima Rice'a powstał w latach 1976-1978. W kwietniu 1976 roku nagrane zostały wszystkie składające się nań utwory i zaprezentowane w wersji audiowizualnej. Wersja sceniczna natomiast miała swoją premierę 21 czerwca 1978 roku w Prince Edward Theater. O sukcesie i bardzo dużej popularności dzieła - choć nie zabrakło wokół niego także i kontrowersji - świadczy fakt, że między wrześniem 1979 a czerwcem 1983 roku pokazano je na Broadwayu ponad 1900 razy $^{5}$.

\section{Libretto}

Akcja Evity rozpoczyna się w Buenos Aires 26 lipca 1952 roku, kiedy projekcję filmową w kinie przerywa wiadomość o śmierci Evity Perón. Publiczność rozpacza. Na scenie pojawia się kondukt pogrzebowy, który śpiewa Requiem for Evita. W tym momencie zostaje przedstawiony Ché, narrator, który w cyniczny sposób opisuje smutek, jaki nastał w narodzie. W następnej scenie widzimy piętnastoletnią Evę, która słucha koncertu swojego kochanka, Augustina Magaldiego. Po zakończonym recitalu Magaldi mówi Evie, że wyjeżdża do stolicy i musi zakończyć romans. Eva zaczyna go szantażować i domaga się, by ten zabrał ją ze sobą. Magaldi, przyparty do muru, zgadza się. Kiedy tylko przybywają do Buenos Aires, Eva rzuca kochanka, ma bowiem większe ambicje niż życie z prowincjonalnym gitarzystą. Ché ukazuje jej drogę do kariery; Eva zdobywa kolejnych kochanków - fotografa Huevo ${ }^{6}$, biznesmena Emilio oraz szefa stacji radiowej, señora Habona. Następna scena jest przedstawieniem drogi do władzy Juana Peróna, który w końcu zostaje najwyższym przywódcą kraju; pozostali pretendenci z junty wojskowej zostają zabici.

Po trzęsieniu ziemi, które miało miejsce w roku 1944, powstaje pomysł zorganizowania koncertu charytatywnego, na którym ma grać Augstin Magaldi. Wtedy dochodzi do pierwszego spotkania Evy z Perónem. Oboje natychmiast dochodzą do wniosku, że mogą sobie pomóc w karierach. W ten sposób Evita trafia do domu Peróna. Przebywa w nim inna jego kochanka. Eva szybko się jej pozbywa. Dzięki związkowi z generałem Evita zostaje wprowadzona na salony. To jednak nie podoba się ani wojskowym, którzy uważają, że nie powinna mieszać się w sprawy polityczne, ani klasie wyższej, która uważa, że Eva nie jest odpo-

\footnotetext{
${ }^{5}$ Zob.: http://www.andrewlloydwebber.com/about/sydmonton-festival/ [data dostępu: 9.02.2014]; http://www.ibdb.com/production.php?id=3809 [data dostępu: 16.06.2013].

${ }^{6}$ Imię Huovo w języku angielskim brzmi podobnie do słowa ,whoever”, co w thumaczeniu znaczy „ktokolwiek”.
} 
wiednią osobą do reprezentowania kraju. Jednak dzięki wsparciu „descamidos”, czyli ludzi z niższych warstw społecznych, Perón zostaje wybrany prezydentem.

Akt II rozpoczyna się od sceny, w której nowo wybrany prezydent z balkonu pałacu Casa Rosada pozdrawia swoich wyborców. Jednakże największy aplauz uzyskuje po swoim płomiennym przemówieniu Evita. W następnej odsłonie, podczas balu odbywającego się na cześć prezydencji Peróna, Ché zastanawia się nad sławą, jaką zdobyła bohaterka. Ta zmienia swój styl i sposób bycia - staje się damą. W roku 1946 wyrusza w dwumiesięczną podróż, podczas której spotyka się z głowami państw Europy w Hiszpanii, Włoszech i Francji. Skutek tego jest różny, jednakże wraca do kraju w chwale. Następnie Ché wyrzuca Evicie, że zdradziła ludzi, którzy wynieśli ją do władzy. Eva również to czuje i tworzy fundację, która ma wspierać najbiedniejszych, jednakże jej działalność charytatywna okazuje się przynajmniej wątpliwa. Mimo to ludzie nie zauważają nadużyć, do jakich dochodzi w fundacji Evy, i coraz bardziej ją kochają. Przyjmuje ona sakrament w kościele na oczach tysięcy ludzi. Jednak w pewnym momencie ma wizję - rozmawia z Ché, który zarzuca jej wykorzystywanie ludzi. Na końcu sceny Evita przyznaje się do tego, że jest ciężko chora. W następnej scenie Eva leży w szpitalu; dostrzega wtedy, że Perón naprawdę ją kocha. W tym czasie generałowie próbują przekonać prezydenta, że jego żona nie powinna się wtrącać do polityki. Ale Evita chce jednak wymusić na Perónie, aby mianował ją wiceprezydentem. Na koniec sceny Evita upada. Kiedy zaczyna rozumieć, że niedługo umrze, odrzuca myśl o wiceprezydenturze. Po raz ostatni pojawia się przed ludźmi na balkonie Casa Rosada i prosi ich o wybaczenie wszystkiego złego, czego od niej zaznali. Tuż przed śmiercią widzi wszystko to, co zrobiła w życiu - jego dobre i złe strony. W ostatniej scenie medycy balsamują ciało Evity. Jej dusza natomiast prosi o przebaczenie.

W warstwie fabularnej Evita pozostaje pod dużym wpływem opery heroicznej. Ukazuje bowiem problemy społeczne, jakie miały miejsce w latach powojennych w Argentynie, bunt przeciwko władzy oraz życie prostych ludzi. Cała historia osadzona jest na tle burzliwych wydarzeń politycznych. Evita staje się symbolem zmian i reprezentantką narodu, dzięki czemu zyskuje nie tylko zaufanie, lecz także uwielbienie ${ }^{7}$. W Evicie zarazem krytykowana jest elita rządząca. Główne postacie są charakteryzowane jako bezwzględne oraz zaślepione władzą. Takie rozwiązania fabularne zbliżają utwór Webbera i Rice'a do dzieł Gilberta i Sullivana, którzy również w bardzo ostry sposób krytykowali nadużycia władzy w niejednej ze swoich komedii muzycznych.

Można stwierdzić, że w Evicie zostały wykorzystane niemalże wszystkie elementy charakterystyczne dla librett oper heroicznych, m.in. zrywy ludności, beze-

${ }^{7}$ Evitę nazywano Świętą Madonną Argentyny, Duchowym Przywódcą Narodu, Chorążą Ubogich, Męczennicą Pracy, Matką Argentyny, Panią Nadziei. 
ceństwa władzy na tle ważnych wydarzeń historycznych. Równocześnie tekst Evity nawiązuje do cech charakterystycznych gatunku opery balladowej, który zrodził się w XVII stuleciu w Anglii. W Evicie, podobnie jak w operze balladowej, dochodzi do podkreślenia różnorodności grup społecznych poprzez język. Dzieło Andrew Lloyda Webbera i Tima Rice’a zawiera szereg takich przykładów: arystokracji przypisany jest język angielski, wojsku ,żołnierski” (użycie wulgaryzmów), prosta ludność Argentyny natomiast najczęściej używa języka hiszpańskiego. Podobny podział następuje w pierwszych operach balladowych, w późniejszej operze werystycznej, a także w operze XX wieku, co szczególnie uwidacznia się w takich dziełach, jak Opera za trzy grosze Kurta Weilla czy Porgy and Bess George'a Gershwina.

\section{Architektonika}

Evita zachowuje budowę dwuaktową, typową dla musicalu drugiej połowy $\mathrm{XX}$ wieku. Jednakże w porównaniu do wielu dzieł tego gatunku ma bardzo rozbudowaną liczbę scen. Oto dyspozycja obu aktów:

Akt I

I. Requiem for Evita

II. Oh, What a Circus?

III. On This Night of a Thousand Stars

IV. Eva and Magaldi

V. Eva Beware of the City

VI. Buenos Aires

VII. Good Night and Thank You

VIII. The Lady's Got Potential

IX. The Art of the Possible

$\mathrm{X}$. Charity Concert

XI. I'd Be Surprisingly Good For You

XII. Hello and Goodbye

XIII. Another Suitcase in Another Hall

XIV. Perón's Latest Flame

XV. A New Argentina
Akt II

On The Balcony of the Casa Rosada

Don't Cry for Me Argentina

High Flying, Adored

Rainbow High

Rainbow Tour

The Chorus Girl Hasn't Learned the Lines

(You'd Like to Hear)

And the Money Kept Rolling In and Out

Santa Evita

Waltz for Eva and Che

You Must Love Me

She Is A Diamond

Dice Are Rolling

Eva's Final Broadcast

Montage

Lament 
Ze scen składających się na akt I można wyróżnić większe bloki strukturalne. Na przykład pieśń Magaldiego On This Night of a Thousand Stars łączy się ze scenami Eva and Magaldi oraz Eva Beware of the City. Utwór śpiewany przez Magaldiego na jego recitalu przechodzi bezpośrednio w scenę zbiorową (tercet Evy, Magaldiego, Ché oraz małego zespołu chóralnego), w której Eva wymusza na kochanku przeprowadzkę do Buenos Aires. Ta z kolei scena łączy się attacca $\mathrm{z}$ duetem Evity i Magaldiego Eva Beware of the City. Również sceny Goodnight and Thank You oraz The Lady's Got Potential stanowią jedną strukturę, tym razem powiązaną poprzez tematykę obydwu numerów. Mimo braku powiązań muzycznych zauważyć trzeba ich symetrię - pierwszy z nich opisuje wspinanie się Evity na szczyty popularności, drugi natomiast opowiada o dochodzeniu do władzy Peróna.

Nieco inaczej wygląda sytuacja w scenach XII i XIII aktu I. Pomiędzy pieśnią Evity Hello and Goodbye oraz pieśnią kochanki Peróna Another Suitcase in Another Hall pojawia się krótki fragment attacca:

Przykład 1. Attacca pomiędzy scenami Hello and Goodbye oraz Another Suitcase in Another Hall, t. 6-7.

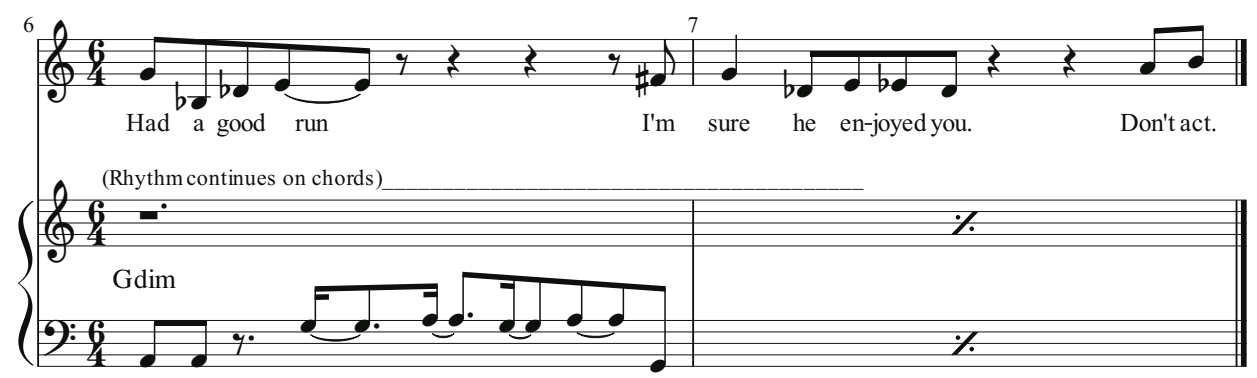

Najokazalej przedstawia się trzyczęściowy finał aktu I. Składa się on z następujących scen: Peron's Latest Flame oraz A New Argentina, pomiędzy którymi umieszczony jest łącznik w postaci duetu Peróna i Evity. Pierwsza część finału składa się z dziesięciu ogniw. Scena początkowa ukazuje bunt przeciwko Evicie, która chce mieć wpływ na politykę i armię. Rozpoczyna ją Ché: 
Przykład 2. Motyw Ché z finału I aktu, t. 4-8.

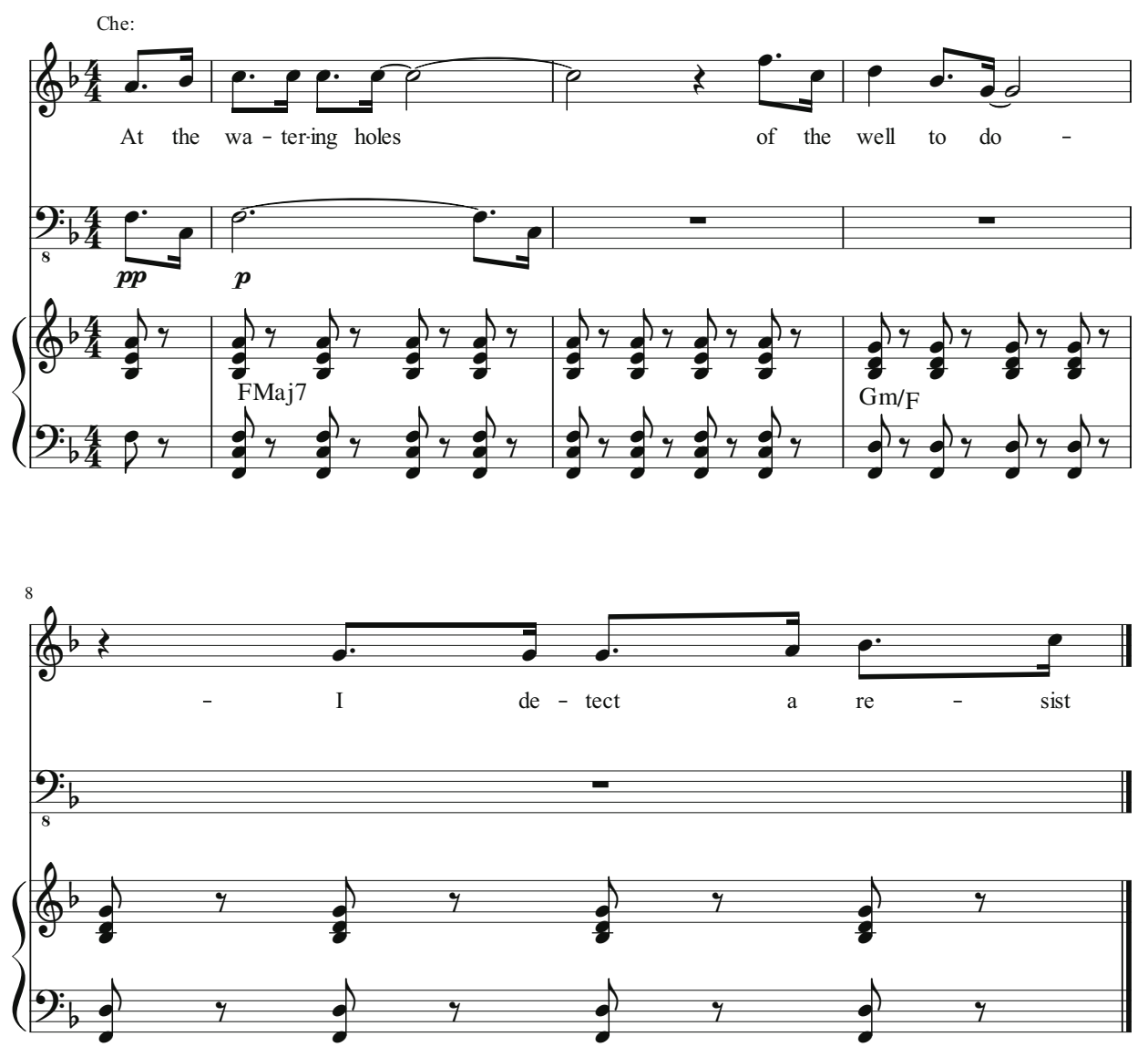

W tym fragmencie Ché wyraża niezadowolenie klas wyższych z powodu możliwości dojścia do władzy głównej bohaterki. Następnie pojawia się chór arystokracji, która osobiście przedstawia swoje obiekcje dotyczące pochodzenia i zachowania Evity: 
Przykład 3. Chór arystokratów z finału aktu I, t. 17-20.

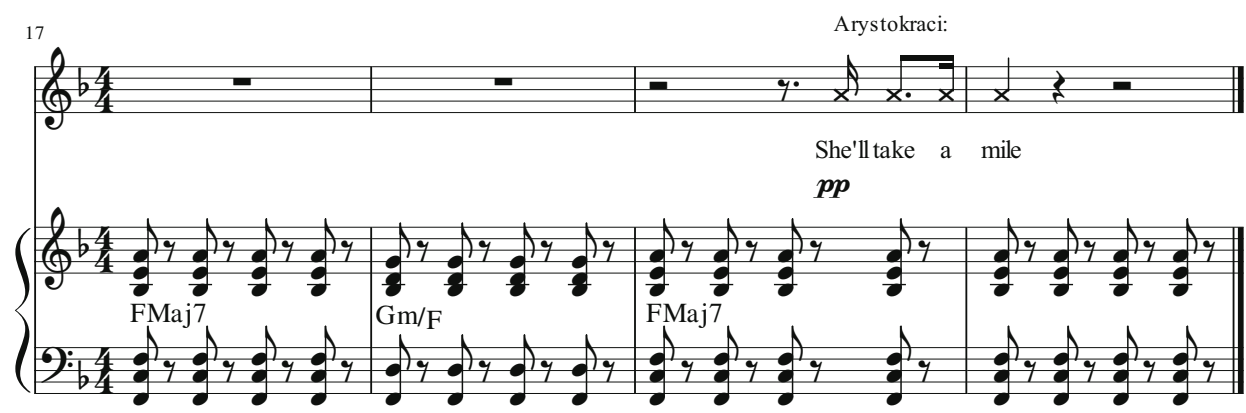

Potem powraca partia Ché z pierwszego ogniwa Perón's Latest Flame. Tym razem jednak przedstawione jest zdanie armii na temat Evity:

Could there be in our fighting corps

A lack of enthusiasm for

Peron's latest flame
W armii też - to się sprawdzić da próżno szukać sympatii dziś dla nowej Pąni eßon"».

Pojawia się wówczas temat charakteryzujący muzycznie żołnierzy:

Przykład 4. Chór wojskowych z finału aktu I, t. 53-56.

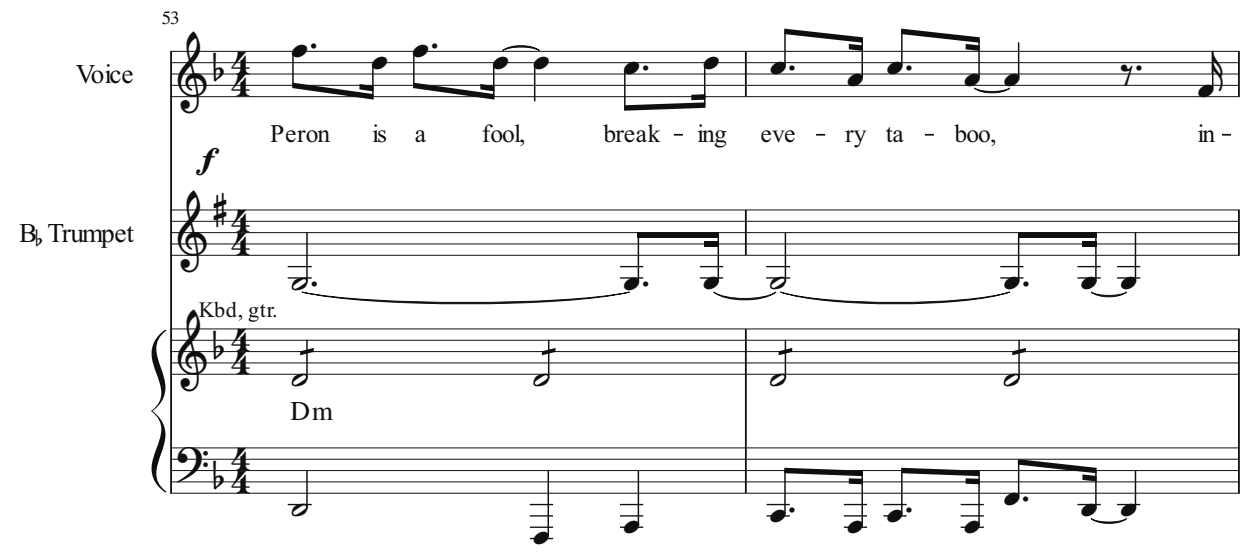

\footnotetext{
${ }^{8}$ Przeł. Andrzej Ozga.
} 


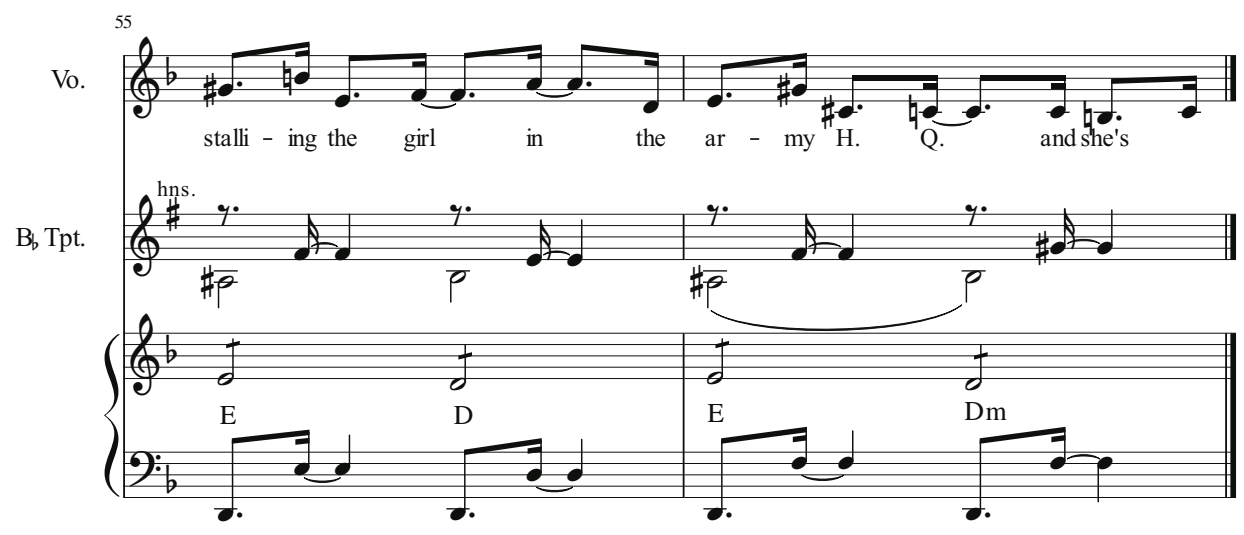

Zabieg zastosowany przez kompozytora i librecistę ma na celu ukazanie Evity w złym świetle. Nie tylko bowiem arystokracja i armia, kierujący się swoimi interesami, lecz także narrator atakuje główną bohaterkę. Chóry naprzemiennie wyrażają swoje zastrzeżenia w stosunku do Evity. Arystokracja podkreśla niskie pochodzenie bohaterki i jej swobodne prowadzenie się. Armię niepokoi jej niepohamowana żądza władzy. Ché natomiast atakuje próżność Evity oraz fakt, że swoją karierę zawdzięcza kochankowi.

W ostatnich dwóch odcinkach pierwszej części finału obydwie grupy bohaterów ponawiają swoje zastrzeżenia. Następnie pojawia się łącznik. Tematycznie powiązany jest on z fragmentem I'd Be Suprisigly Good for You. Kiedy Juan Perón zastanawia się nad tym, czy rzeczywiście chce sprawować władzę, i rozmawia o tym z Evitą, następuje moment przełomowy. Na końcu sceny generał zostaje aresztowany, gdyż armia uznała, że nie może pozwolić na tak duże wpływy jego kochanki. Mimo sprzeciwu wojskowych lud w tle skanduje: „Pe-rón! Pe-rón!”. Scena ta zatem bezpośrednio przeistacza się w bunt thumu. Gdy ludzie zaczynają się buntować, następuje muzyczna odpowiedź Evity.

Po fragmencie o charakterze responsorialnym (chór - Evita - chór - Evita - chór) następuje scena, w której bohaterka przybywa do więzienia i próbuje namówić Peróna, by jednak zdecydował się na przejęcie władzy. Ten w końcu zgadza się, gdyż ostatnia partia chóru go przekonuje.

Scena I aktu II rozpoczyna się od przemówienia Juana Peróna. Jest to parlando na tle chóru skandującego „Perón!”, jednak w pewnym momencie okrzyk zaczyna przeradzać się w wołanie „Evi-ta! Evi-ta!”: 
Przykład 5. Chór ze sceny Balcony of Casa Rosada, t. 44-53.
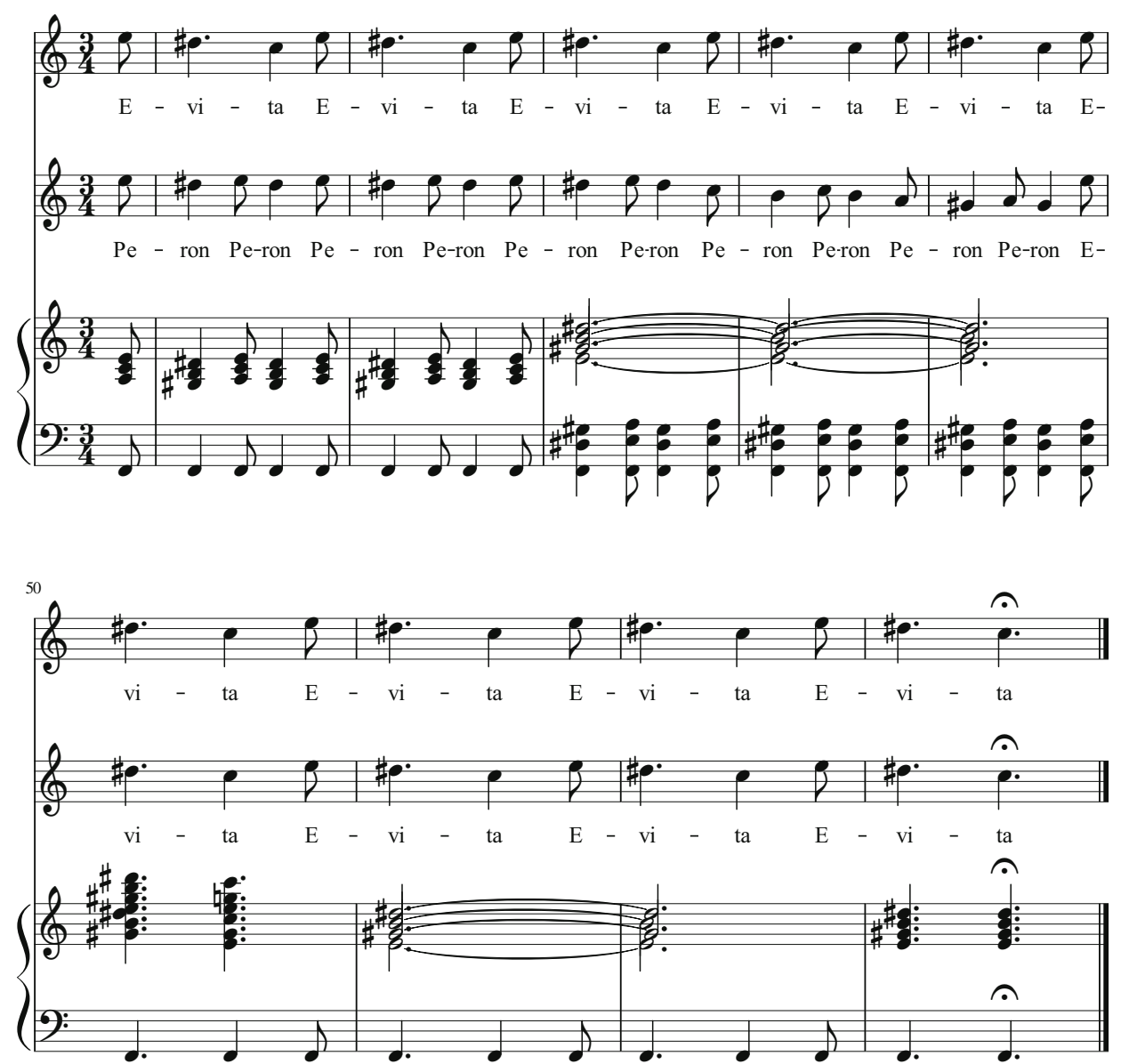

Kompozytor ukazuje zmianę nastawienia do Evity, która odtąd staje się w polityce postacią pierwszoplanową, a następnie bezpośrednio przechodzi do słynnej ceny przemowy Evity, Don't Cry for Me Argentina. Co ciekawe, Lloyd Webber zastosował przy tej okazji zdecydowanie odmienne opracowanie partii wokalnych: w pierwszej części omawianego bloku scenicznego przemowa Peróna jest sucha i konkretna, na tle bardzo ograniczonego akompaniamentu. Przemowa Evity natomiast jest bardzo melodyjna - pragnie dotrzeć do uczuć ludzi. Tło instrumentalne staje się wówczas bardzo rozbudowane; wprowadzone zostaje tutti z dominującą rolą kwintetu smyczkowego oraz instrumentów dętych blaszanych.

Następnym blokiem scenicznym są numery Rainbow High oraz Rainbow Tour. W pierwszym z nich przedstawiona zostaje przemiana bohaterki ze zwykłej dziewczyny na prawdziwą damę. Zmiana wizerunku służyć ma przede wszystkim promo- 
waniu polityki Peróna w Europie, co jest przedstawione w scenie następnej. Obydwa ujęcia połączone są ze sobą krótką przemową prezydenta. Kompozytor łączy również bezpośrednio ze sobą sceny The Actress Hasn't Learned the Lines (You'd Like to Hear) oraz And the Money Kept Rolling In (and Out), ponownie za pomocą łącznika. Pierwsza ze scen rozpoczyna się chórem arystokracji, jednak ten przeradza się w dialog pomiędzy Evitą, która przemawia do klasy wyższej, i Ché, który zarzuca jej, że los Argentyńczyków nie zmienił się. Evita odpowiada, że wszystkie problemy zostaną rozwiązane dzięki jej fundacji. W ten sposób scena przeradza się w scenę And the Money Kept Rolling In (and Out), która jest krytyką fundacji Evity.

Budowa wewnętrzna poszczególnych scen musicalu przedstawia się w bardzo różny sposób. Uwertura do Evity zachowuje budowę czteroczęściową: $\mathrm{A}-\mathrm{B}-\mathrm{A}^{1}-\mathrm{B}^{1}$. Pierwsza część, przeznaczona wyłącznie na instrumenty, utrzymana jest w tonacji e-moll, a jej charakterystyczną cechą jest zmienne metrum. W drugiej części uwertury zostaje wprowadzony chór. Harmonika, mimo iż utrzymana w tonacji e-moll, opiera się na nietypowej relacji: V stopień obniżony - I stopień. W ostatnich taktach drugiej sekcji uwertury wprowadzona jest modulacja do tonacji a-moll. Trzecie i czwarte ogniwo uwertury są powtórzeniami pierwszych dwóch sekcji ze zmianą tonacji na a-moll. Kompozytor inaczej również instrumentuje stosowane tematy. O ile w pierwszej sekcji temat grany był przez waltornię, o tyle w sekcji trzeciej wykonują go skrzypce i flety poprzeczne, a później również waltornie i trąbki. W czwartym ogniwie natomiast zostaje wprowadzona gitara basowa, która wprowadza mocniejszy puls.

Najczęściej występującym klasycznym układem formalnym jest w Evicie pieśń zwrotkowa $\mathrm{z}$ refrenem. Taka zasada budowy występuje w The Lady Got Potential (A - B - A - B - A - B - B - A), Don't Cry for Me Argentina (A - B $\left.-\mathrm{A}-\mathrm{B}^{1}-\mathrm{B}-\mathrm{A}\right)$, And the Money Kept Rolling In (and Out) $(\mathrm{A}-\mathrm{B}-\mathrm{A}-\mathrm{B}-\mathrm{A}-$ $\left.\mathrm{B}-\mathrm{A}^{1}-\mathrm{A}-\mathrm{B}\right)$ oraz $\mathrm{w} A$ Waltz and Eva and Ché $\left(\mathrm{A}-\mathrm{B}-\mathrm{A}-\mathrm{B}-\mathrm{A}^{1}-\mathrm{C}\right.$, gdzie cząstka $\mathrm{C}$ jest rodzajem epilogu). Podobnie Buenos Aires w dużej mierze wykazuje układ zwrotkowo-refrenowy o budowie: $\mathrm{A}-\mathrm{B}-\mathrm{A}^{1}-\mathrm{B}-\mathrm{A}-\mathrm{C}-\mathrm{A}^{2}-\mathrm{B}-$ $\mathrm{A}$; odcinek $\mathrm{C}$ stanowi jednak bardzo krótkie interludium, które nieco przełamuje schematyzm zwrotkowej formy utworu.

Charakterystyczna dla Evity jest także forma kupletowa. Pojawia się ona dwukrotnie: najpierw w I'd Be Suprisigly Good for You o budowie czteroczłonowej oraz w uwerturze do aktu II o budowie $\mathrm{A}-\mathrm{A}-\mathrm{A}-\mathrm{A}^{1}$ (pierwsze trzy człony są instrumentalne, ostatni - wokalno-instrumentalny).

W utworze Oh, What a Circus? występuje cabaletta zbudowana z dwóch części. Pierwsza część utrzymana jest w metrum 4/4, w rytmie rumby ${ }^{9} \mathrm{i}$ w tonacji E-dur:

\footnotetext{
${ }^{9}$ Charakterystyczny dla tego tańca jest nieregularny podział taktu, w którym osiem ósemek dzieli się na trzy grupy: 3+3+2. Por. hasło Rumba, [w:] Encyklopedia muzyki, red. A. Chodkowski, Warszawa 1995, s. 778.
} 
Przykład 6. Fragment sceny Oh, What a Circus? z aktu I, t. 29-32.

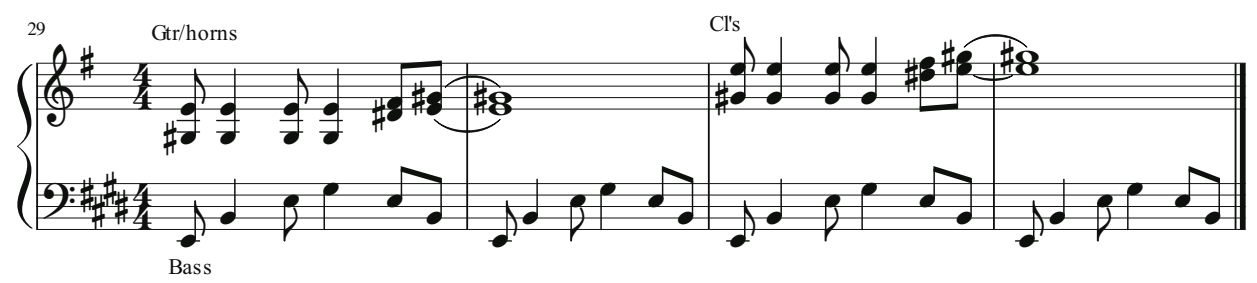

Ché zastanawia się w tym miejscu nad główną bohaterką, nad którą w tle płacze thum. Pyta o to, co zrobiła takiego, że wszyscy cierpią z powodu jej odejścia? Druga część cabaletty utrzymana jest $\mathrm{w}$ takcie alla breve, w akompaniamencie występują równe wartości rytmiczne, zmienia się również instrumentacja - o ile wcześniej była to gitara klasyczna, o tyle teraz zastępuje ją przesterowana gitara elektryczna. Ta część cabaletty przedstawia wydarzenia, które miały miejsce za czasów rządów męża Evity - liczne protesty, armia na ulicach oraz uciszanie mediów. W ten sposób librecista i kompozytor ukazują zarys tego, co będzie działo się podczas całego musicalu. Ponadto, zgodnie z tradycją XIX-wiecznego gatunku cabaletty, następuje tu znaczne zintensyfikowanie emocji.

Pozostałe pieśni wykazują dość nieregularną budowę. Jednakże można zauważyć w nich pewne prawidłowości. Spora grupa różnych numerów zachowuje, przynajmniej częściowo, budowę zwrotkową. Tak na przykład Eva and Magaldi / Eva Beware of the City w pierwszej części numeru daje się sprawdzić do układu: $\mathrm{A}-\mathrm{B}-\mathrm{A} 1-\mathrm{C}-\mathrm{B}-\mathrm{D}-\mathrm{E}-\mathrm{F}-\mathrm{G}-\mathrm{F}-\mathrm{G}-\mathrm{F}$. Ostatnich jego pięć członów jest pieśnią zwrotkową, jednakże całość charakteryzuje duża różnorodność melodyczna i rytmiczna. W podobny sposób kształtuje się forma Rainbow High, tym razem jednak od układu o budowie zwrotkowej rozpoczyna się cały numer: $\mathrm{A}-\mathrm{B}-\mathrm{A}-\mathrm{B}-\mathrm{A}-\mathrm{C}-\mathrm{B}^{1}-\mathrm{D}-\mathrm{E}$.

Rozbudowanie układu zwrotkowego o dodatkowe człony najczęściej wiąże się z architektoniką całych bloków scenicznych. Części „obce”, tzn. występujące jednostkowo, stanowią najczęściej łącznik do scen następnych bądź są powiązane motywicznie ze scenami poprzednimi. Do pewnego stopnia regularny układ ma również Goodnight and Thank You: $\mathrm{A}-\mathrm{B}-\mathrm{C}-\mathrm{A}-\mathrm{B}-\mathrm{C}-\mathrm{D}-\mathrm{A}-\mathrm{B}-\mathrm{B}^{1}$. Zasadą jest w tym wypadku utrzymanie nierozłączności ogniw A i B. Natomiast najbardziej skomplikowanym motywicznie utworem jest Rainbow Tour, który posiada budowę: $\mathrm{A}-\mathrm{B}-\mathrm{C}-\mathrm{A}-\mathrm{D}-\mathrm{A}-\mathrm{B}-\mathrm{A}^{1}-\mathrm{B}-\mathrm{B}^{1}$.

W swej zewnętrznej budowie Evita nawiązuje do oper Gilberta i Sullivana oraz amerykańskiego musicalu XX wieku. Utwory sceniczne duetu Gilbert-Sallivan składały się zwykle z dwóch aktów i zazwyczaj nie trwały dłużej niż dwie 
godziny. Taki model adoptowany został również w Stanach Zjednoczonych na początku XX wieku i przeniknął do twórczości większości kompozytorów broadwayowskich. Marek Gołębiowski wskazuje na pragmatyzm tego zabiegu. Przedstawienia zazwyczaj rozpoczynały się około godziny 21, przez co mieszkańcy dzielnic położonych na przedmieściach musieli po spektaklu wracać późnym wieczorem. Zarówno dla teatrów w Londynie, jak i w Nowym Jorku długość spektaklu miała zatem olbrzymie znaczenie. Gdyby musicale trwały dłużej, mogłoby się to niekorzystnie odbić na frekwencji, przez to również i na finansach ośrodka ${ }^{10}$. Lloyd Webber prawdopodobnie (na co wskazuje budowa innych jego dzieł scenicznych, poza Tell Me on Sunday i okolicznościowym Cricket) również przyjął taki model ze względów pragmatycznych.

\section{Rytm i stylizacja. Zabiegi archaizacyjne}

W warstwie rytmicznej i stylizacyjnej Lloyd Webber stosuje bogatą paletę środków. W samej partyturze bardzo często stosowane są oznaczenia odnoszące się do zabiegu stylizacji. Dotyczy ona w głównej mierze kwestii rytmicznych i wyrazowych (stąd sugestie typu „funeral”, „funky” czy „tango”). Najbardziej eksponowaną rolę odgrywają w Evicie klasyczne rytmy tańców latynoamerykańskich. Na przykład w numerze $O$ h, What a Circus? występuje rytm beguine ${ }^{11}$, a w kolejnych scenach pojawiają się stylizowane rumba, salsa i tango, a także rytmy meksykańskie. Wykorzystanie tańców latynoamerykańskich ma na celu wprowadzenie słuchacza w atmosferę Argentyny. W każdej z tych scen przedstawiona zostaje argentyńska ulica, nie jest to bowiem muzyka sfer wyższych. Jedynie tango w wykonaniu Magaldiego pojawia się w scenie koncertu charytatywnego. Należy jednak pamiętać, że sam Magaldi zaczynał swoją karierę w klubach i kawiarniach pod Buenos Aires.

Do przedstawiania innych grup społecznych w Argentynie Lloyd Webber również wykorzystuje tańce. Na przykład armię charakteryzuje z reguły rytm marszowy. W analogiczny sposób przedstawiana jest arystokracja, jednakże nie w opracowaniu instrumentalnym, lecz poprzez śpiew chóralny a cappella:

\footnotetext{
${ }^{10}$ Gołębiowski, op. cit., s. 101-102.

${ }^{11}$ Beguine - taniec w parzystym metrum i umiarkowanym tempie, pochodzący z Martyniki. Popularność zdobył dzięki Cole Porterowi.
} 
Przykład 7. Chór arystokratów ze sceny Peron Latest Flame, t. 143-144.

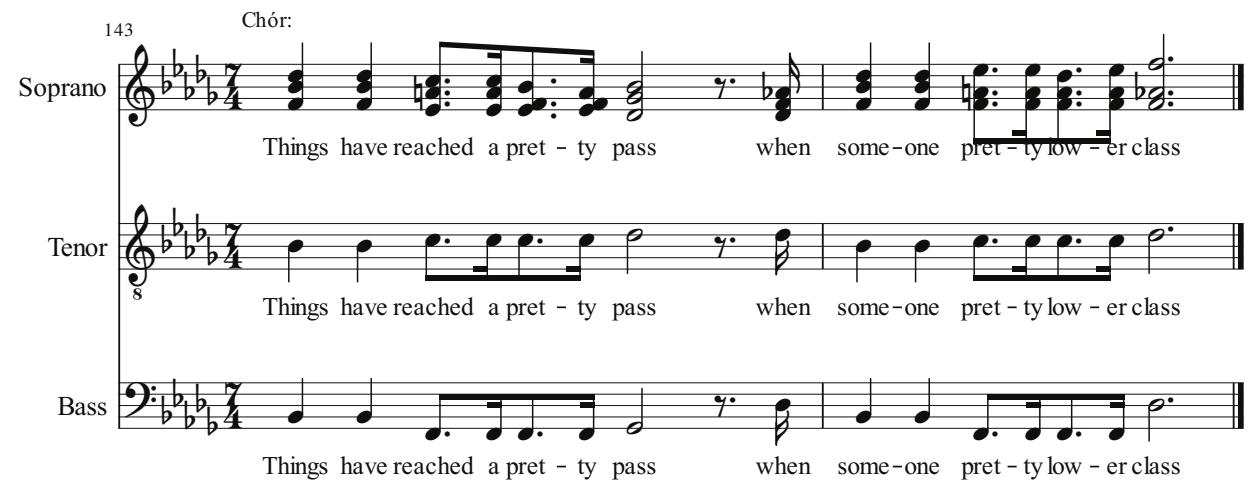

Metrum zmienia się tu wprawdzie na $7 / 4$, ale charakter marszowy jest cały czas wyczuwalny.

W Evicie wykorzystany zostaje również walc wiedeński. Pojawia się on na przykład w scenie Waltz for Evita and Ché, w której podczas tańca obydwoje, Evita i Ché, wypominają sobie swoje błędy:

Przykład 8. Fragment sceny Waltz for Evita and Ché, t. 3-6.
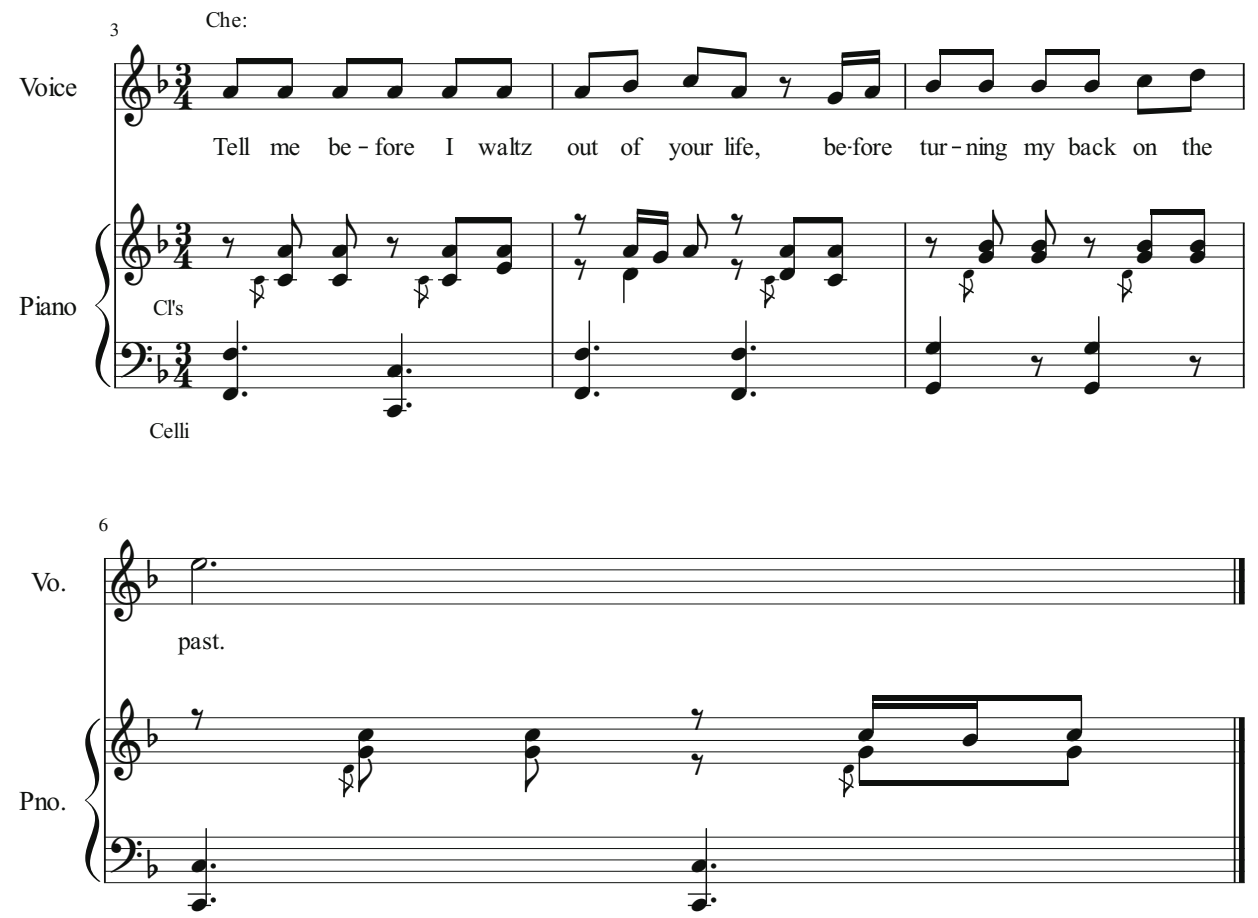
Zastosowanie rytmów tanecznych różnego pochodzenia, zarówno latynoamerykańskich, jak i europejskich, przywodzi na myśl dwa źródła inspiracji. Po pierwsze, stylizacje Webbera budzą skojarzenia z operetką wiedeńską XIX wie$\mathrm{ku}$, w której warstwa rytmiczna opierała się w dużej mierze na walcach; często występowały tam także tańce ludowe (np. Księżniczka czardasza), których zadaniem było rozgraniczenie świata salonu od świata ludu. Po drugie, źródłem tych zabiegów wydaje się opera heroiczna, w której w scenach przedstawiających bunt (Niema z Portici, Hugenoci) stosowano zwykle rytmy marszowe. Ważnym źródłem jest również twórczość George’a Gershwina, zwłaszcza środki stylizacyjne, jakie kompozytor ten wprowadził w swoich operach jazzowych i utworach instrumentalnych. W podobny sposób Andrew Lloyd Webber stosuje stylizację w Evicie. Tak jak Gershwin charakteryzował różnice pomiędzy mieszkańcami miasteczka portowego w Porgy and Bess, tak Lloyd Webber charakteryzuje prostych Argentyńczyków przedstawionych w Evicie.

W Evicie kompozytor dokonuje również kilku zabiegów archaizacyjnych, świadomie stosując rozwiązania nawiązujące do technik kompozytorskich czy innych zjawisk muzycznych znanych z przeszłości. Wyróżnić można tu dwa typy archaizacji. Pierwszy wiąże się z przywołaniem słów mszy żałobnej. W uwerturze do aktu I zostaje użyty trawestowany tekst z missa pro defunctis - „Requiem aeternam Dona Evita”. Podkreśleniu tekstu służy utrzymywanie faktury homofonicznej, a akompaniament opiera się na instrumentach dętych blaszanych, perkusyjnych i smyczkowych, przy eksponowanej roli instrumentów dętych blaszanych (tu w szczególności najwyraźniej brzmiących partii trąbek) i perkusyjnych (szczególne znaczenie kompozytor nadaje kotłom, które podkreślają znaczenie słowa Evita). W analogiczny sposób Webber archaizuje partię chóru dziecięcego w Oh, What a Circus?. Kompozytor wykorzystuje tu oryginalny tekst antyfony Salve Regina, w którym podmienia imię Ewy. Łaciński tekst „Exsules filii Hevae” zmienia się w Evicie na „Excules filii Eva”. W przekładzie jest to jedno i to samo, jednak autor tekstu chciał podkreślić, o którą Ewę w tym wypadku chodzi. Dodaje też nazwisko „Perón”. Ważnym elementem w tej scenie jest wykorzystanie organów, które mają podkreślić podniosły charakter sytuacji. Na koniec sceny Oh, What a Circus? zostaje powtórzona partia chóru, jednak tym razem pojawia się ona w odmiennym opracowaniu. Chór rozpoczyna w unisonie, lecz w pewnym momencie wprowadzona zostaje technika discantowa, polegająca na usamodzielnieniu się dwóch głosów: 
Przykład 9. Partia chóru ze sceny Oh, What a Circus?, t. 156-162.
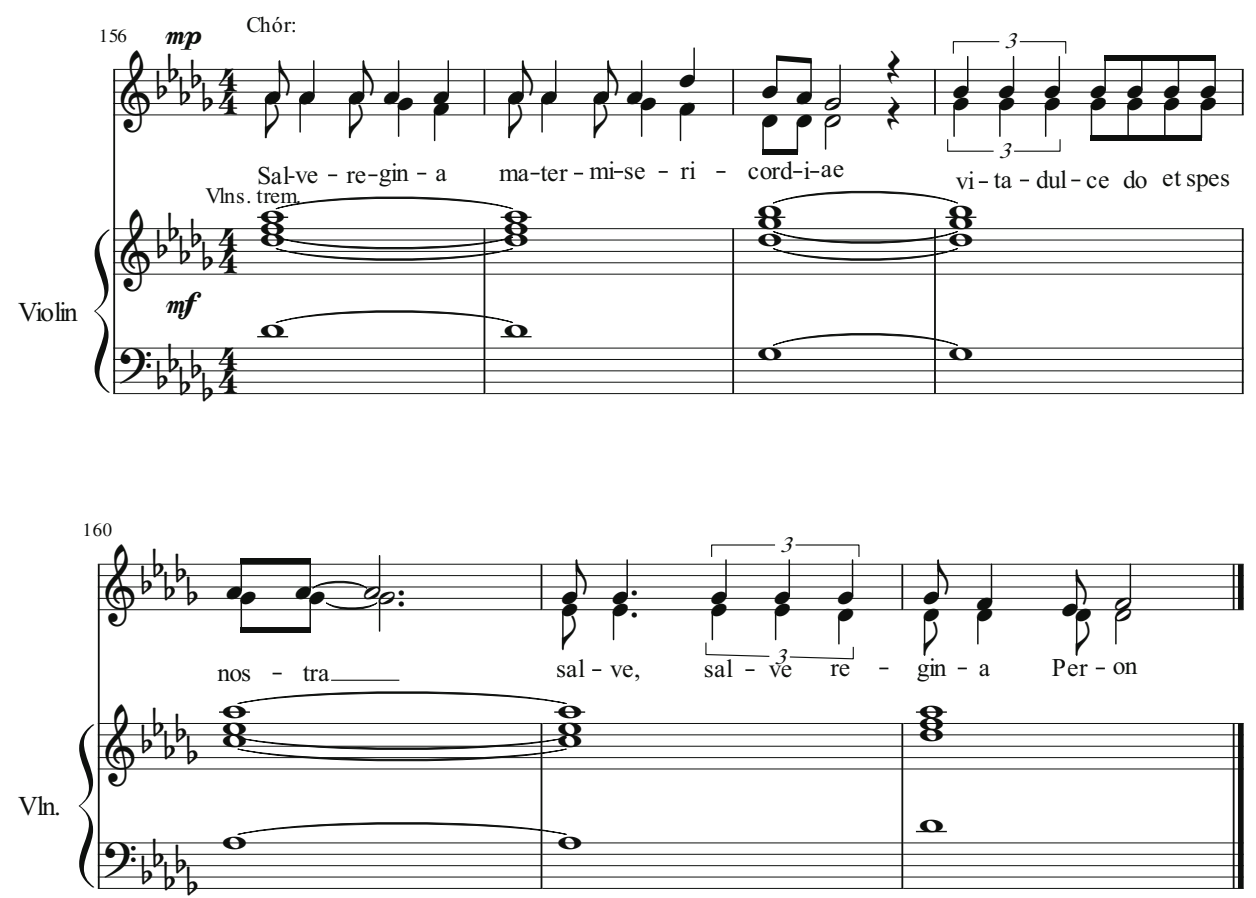

Drugi typ wykorzystywanej przez Webbera archaizacji obejmuje sferę melodyki. Kompozytor wykorzystuje bowiem hymniczne opracowanie tekstu. W taki sposób potraktowane zostają partie chóru arystokracji. Zabieg ten podkreśla pochodzenie argentyńskich arystokratów, gdyż w znakomitej większości byli to obywatele Wielkiej Brytanii. Podobne rozwiązanie stosuje kompozytor także w scenie Santa Evita, gdzie zostaje wprowadzony chór dziecięcy. W tej scenie powtórzony zostaje materiał melodyczny ze sceny $O$ h, What a Circus?, ale język zostaje tu zmieniony na hiszpański. Wynika to $\mathrm{z}$ treści libretta, dzieci śpiewające $\mathrm{w}$ chórze bowiem zwracają się do Evity jako do „matki wszystkich argentyńskich matek”.

Archaizacja wykorzystana przez kompozytora w Evicie przywołuje na myśl operę heroiczną. Zarówno w musicalu Lloyda Webbera, jak i u kompozytorów XIX-wiecznych stosowanie archaizacji miało bowiem na celu podkreślenie podniosłości, wagi niektórych wydarzeń, jak na przykład w Hugonotach Meyerbeera, gdzie w analogicznych momentach wykorzystany zostaje chór a cappella. W Evicie archaizacja występuje tylko w scenach, w których ukazane są ważkie sytuacje, jak w scenie Oh, What a Circus?, obrazującej Argentynę po śmierci prezydentowej. Warto przy tym pamiętać, że jej pogrzeb zgromadził około trzy miliony osób, które - by zobaczyć ją po raz ostatni - czekały w kolejce w ulewnym deszczu nawet piętnaście godzin. 


\section{Motywy przypominające}

Ważnym elementem integrującym Evitę jest czynnik melodyczno-motywiczny. Kompozytor stosuje w tym zakresie wiele środków, które budują jedność dzieła. Najważniejszym z nich są motywy przypominające, pojawiające się na przestrzeni całego utworu.

Wielu autorów zajmujących się tematyką musicalu - w tym i musicalami Webbera - interpretuje motywy występujące w dziełach tego nurtu jako motywy przewodnie. Kompozytor i autor licznych publikacji na temat teatru muzycznego, Scott Miller, pisze w swoim artykule Inside Evita:

„W Jesus Christ Superstar Andrew Lloyd Webber czasami powtarza motywy muzyczne, tworząc «lejtmotywy» [...], lecz czasami ich wykorzystanie jest incydentalne. W późniejszych dziełach, takich jak Koty oraz Upiór w operze, powtarzalność motywów ma charakter całkowicie przypadkowy i nie ma charakteru dramatycznego. Dopiero w Evicie, idąc za Wagnerem i Sondheimem, Webber - wprowadzając poszczególne motywy - nadaje im znaczenie wiążące, opisujące bohatera, dające subtelny komentarz do akcji scenicznej”’12.

Leitmotiv w ujęciu wagnerowskim stanowi jednakże dużo bardziej kompleksową formę wyrazu aniżeli Erinnerungsmotiv występujący w dziełach operowych (np. Czarodziejski flet i Don Giovanni Wolfganga Amadeusza Mozarta, Wolny strzelec Carla Marii Webera) czy symfoniach programowych poprzedzających dramat muzyczny (np. Symfonia fantastyczna Hectora Berlioza). Po pierwsze, rolę odgrywa tu czynnik ilościowy. Liczba lejtmotywów w późnych dziełach scenicznych Richarda Wagnera (po Lohengrinie) znacząco przewyższa liczbę motywów przypominających w wielkich dziełach operowych późnoromantycznych kompozytorów francuskich czy w Evicie. Po drugie, istotne rozróżnienie stanowi aspekt głębokości warstwy motywicznej. Jak pisze Andrew Whittall'13, „problemem motywów przewodnich jest ich wieloznaczność” ${ }^{14}$. Motyw ukazujący „odkupienie przez miłość” z tetralogii Pierścień Nibelunga równocześnie reprezentuje ,apoteozę Brunhildy”. Dodatkowo lejtmotyw może przedstawiać dużo większą paletę zjawisk: osobę, miejsce, przedmiot, ideę, stan umysłu, siły ponadnaturalne, ale także pozostałe elementy dzieła scenicznego. Co najważniejsze, motywy przewodnie w ujęciu wagnerowskim stanowią podstawowy element

${ }^{12}$ Miller, op. cit.

${ }^{13}$ A. Whittall, Leitmotiv, [w:] The New Grove Guide to Wagner and His Operas, red. B. Millington, Oksford 2006, s. 153-160.

${ }^{14}$ Ibid., s. 154. 
poetyki utworu, podstawowe komórki „niekończącej się melodii”. Najbardziej rozpoznawalny „motyw Tristana”, który po raz pierwszy uwidacznia się w Vorspielu do dramatu muzycznego Tristan i Izolda, uwidacznia różnicę pomiędzy zasadą tworzenia motywów przewodnich a motywów przypominających. Pierwszą część Vorspielu kompozytor w całości podporządkowuje schematowi motywicznemu poprzez ciągłą jego progresję. W późniejszym przebiegu dzieła motyw powraca w przekształconych wersjach. Dochodzi tu do przetworzenia podobnego do tego, jakie występuje w allegrze sonatowym. W ostatniej części Wagner wraca do tematu w jego niezmienionej formie, nadając całości charakter repryzowy.

Rola motywów przypominających w musicalach Andrew Lloyda Webbera jest nieco odmienna. Poszczególne motywy kompozytor przypisuje konkretnym postaciom, ich cechom charakteru bądź określonym sytuacjom. Dodatkowo charakter konstrukcyjny motywów przypominających ogranicza się do wewnętrznej struktury poszczególnych numerów muzycznych. W przeciwieństwie do wagnerowskiej idei lejtmotywów motywy przypominające nie rozpościerają się ponad zamknięty schemat muzyczny, lecz ograniczają się do zaakcentowania sfery semantyczno-symbolicznej, przy jednoczesnym zredukowaniu ich oddziaływania architektonicznego i formalnego.

Często występującym motywem przypominającym jest „I motyw Evity”:

Przykład 10. „I motyw Evity” ze sceny What a Circus?, t. 33-47.
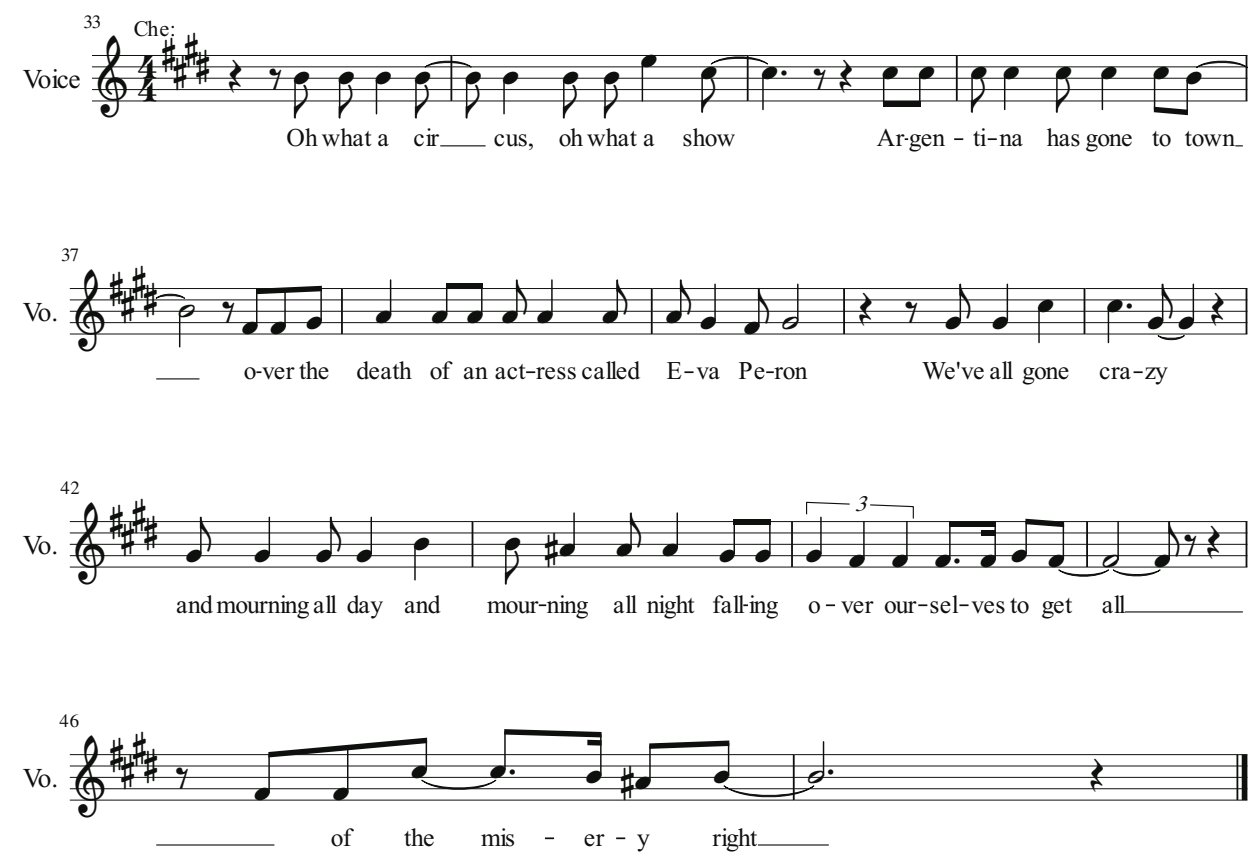
Najczęściej przypisywany jest on samej bohaterce. Wykorzystany został w scenach: Oh, What a Circus?, Don't Cry for Me Argentina oraz Eva's Final Broadcast. Za każdym razem występuje w kontekście sposobu postrzegania Evity przez mieszkańców Argentyny. W Oh, What a Circus? motyw ten wykonują kolejno Ché, chór dziecięcy oraz Evita. Każda partia jest inaczej opracowana - w partii narratora występuje stylizowana rumba, partie chóralne zostają poddane archaizacji, natomiast partia Evity ma charakter pieśni. Wiąże się za tym również zmiana przekazu: w partii Ché jest to cyniczne traktowanie historii bohaterki, w drugiej (gdzie występuje chór) uświęcenie Evity, w ostatniej natomiast Evita, na słowach „Don’t Cry for Me Argentina", podkreśla swe poświęcenie dla Argentyńczyków. W dwóch innych scenach, w których występuje „I motyw Evity”, Don't Cry for Me Argentina oraz Eva's Final Broadcast, zostaje on włączony w przemówienia Evity. Za każdym razem przemówienia te są pełne czułości i pokory. Cechy te jednak w bardzo niewielkim stopniu charakteryzują bohaterkę. Co więcej, kompozytor wykorzystuje „I motyw Evity” wyłącznie w sytuacjach publicznych, gdzie Evita musi pokazać się od innej strony.

Omawiany motyw zostaje ponadto wykorzystany w scenie Santa Evita i śpiewany jest przez chór dziecięcy:

Przykład 11. Chór dziecięcy ze sceny Santa Evita, t. 4-9.
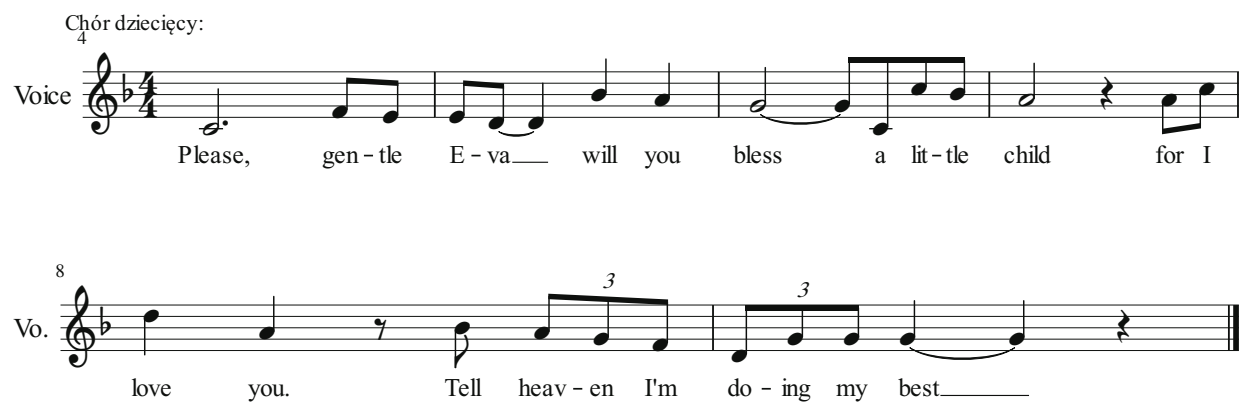

Osobowość bohaterki najlepiej oddają dwa inne motywy. Pierwszy z nich reprezentuje jej żądzę kariery:

Przykład 12. „II motyw Evity” ze sceny Eva and Magaldi, t. 158-162.

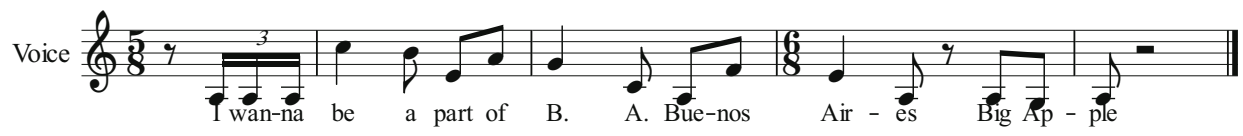

Motyw ten pojawia się również w scenie, kiedy Evita odwiedza osadzonego w areszcie Peróna. Wtedy swoje marzenia o „Big Apple” wyraża w dużo ostrzej- 
szym tonie („Nie zamykajmy sobie drzwi, ponieważ możemy stracić Big Apple"). Librecista, by podkreślić charakter wypowiedzi bohaterki, dodał w partyturze komentarz wykonawczy „,cool voice”, czyli „spokojnym głosem”. Evita już wie, czego chce, jej marzenia mogą się spełnić, jeśli tylko Perón pójdzie o krok dalej. Fragmenty motywu pojawiają się jeszcze w scenie Rainbow High, w której Evita planuje, że osiągnie sukces nie tylko w Argentynie, ale na całym świecie:

Przykład 13. „II motyw Evity” ze sceny Rainbow Tour, t. 68-70.
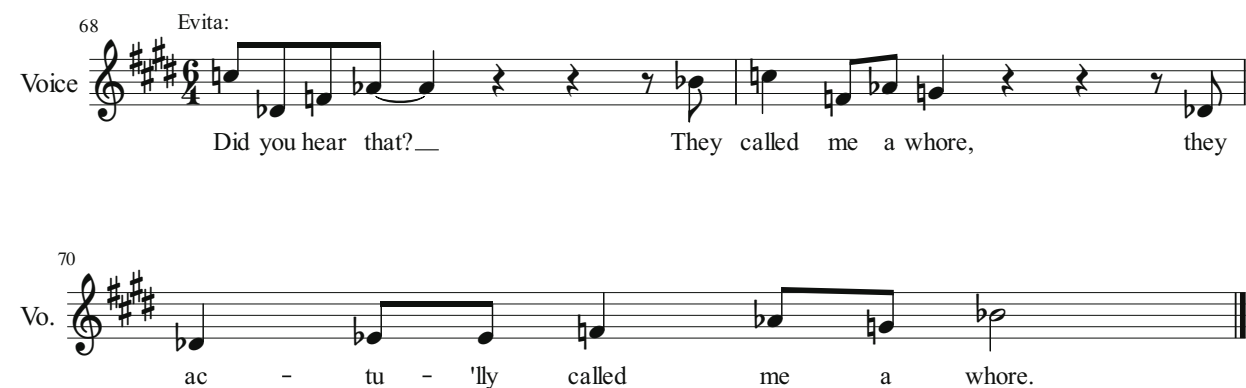

Scena ta zdaje się być punktem kulminacyjnym musicalu. Ukazuje bowiem szczyt popularności Evity. Później sama bohaterka zaczyna ją tracić, a jej władza nie cieszy się już tak wielkim poparciem. W tym szczytowym momencie zestawione zostają najistotniejsze motywy przypominające występujące na przestrzeni dzieła. Poza „II motywem Evity” jest tam również „motyw śmierci”, znany z Requiem for Evita:

Przykład 14. „Motyw śmierci” z Uwertury, t. 1-6.

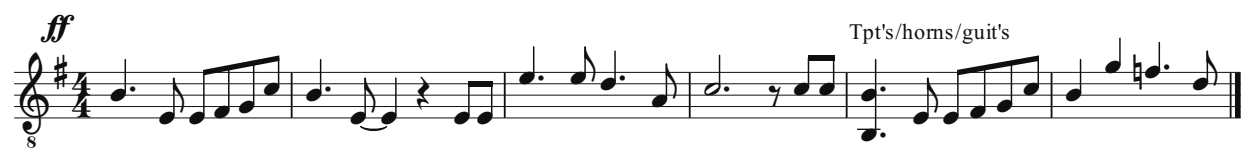

O ile w Rainbow High miał on minorowy charakter, to tutaj występuje w tonacji durowej, a w ostatnim takcie pojawia się w nim charakterystyczny skok interwałowy (seksta wielka w górę, sekunda wielka w dół, t. 32):

Przykład 15. Przekształcony „motyw śmierci” ze sceny Rainbow High, t. 31-32.

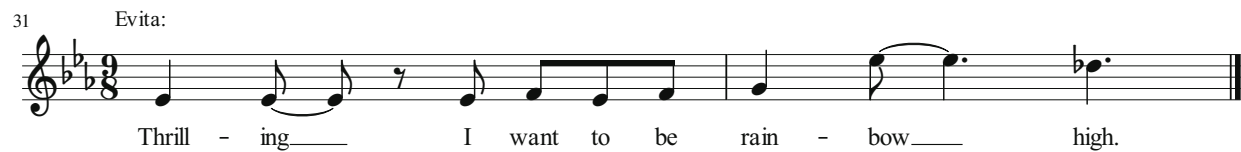


Motyw ze sceny Rainbow High ma charakter zupełnie przeciwny do funeralnego, towarzyszy bowiem tekstowi, w którym ,życie” zostaje podkreślone słowami: „I want to be rainbow high!” („Chcę być tęczą wysoko, o tak!”).

Z kolei w scenie Lament motyw ten przejmuje Evita, która zdaje sobie sprawę z nadchodzącej śmierci:

Przykład 16. Partia Evity ze sceny Lament, t. 1-9.
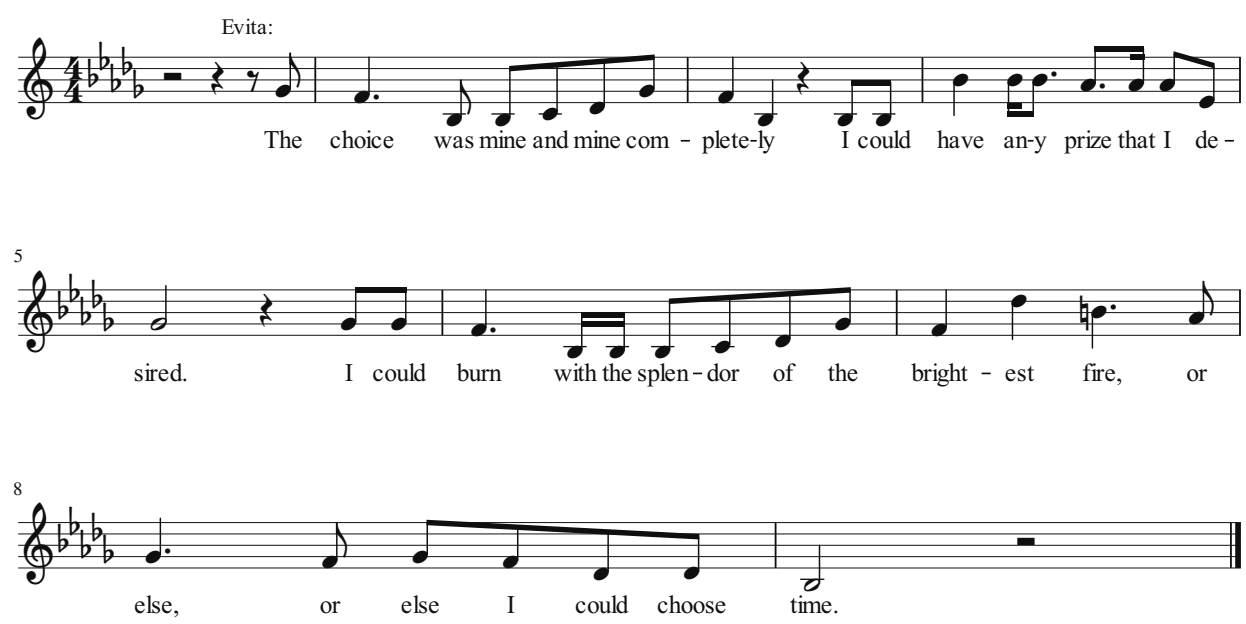

Charakterystyczny skok interwałowy użyty jest tu na słowie „brightest” („najjaśniejszy”), wcześniej towarzyszący zbitce „rainbow high” („tęczą wysoko”). Świadczyć to może o próbie wykorzystania przez kompozytora pewnych elementów retoryki muzycznej, w której dosyć często na słowach podkreślających uniesienie, szczególne emocje, wysokie położenie, wykorzystywano ascendentalny skok interwałowy ${ }^{15}$.

Na powiązanie tematyczne sceny Rainbow High ze sceną Lament wskazuje również partia chóru męskiego:

Przykład 17. Partia chóru męskiego ze sceny Rainbow High, t. 7-10.

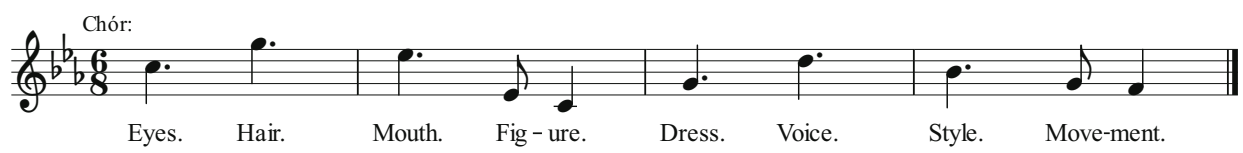

\footnotetext{
${ }^{15}$ Por. T. Jasiński, Polska barokowa retoryka muzyczna, Lublin 2009, s. 306, passim.
} 
Ów motyw melodyczny, który charakteryzuje stylistów głównej bohaterki, zostaje później przejęty przez balsamistów, przygotowujących ją na ostatnią drogę:

Przykład 18. Partia chóru balsamistów ze sceny Lament, t. 28-31.

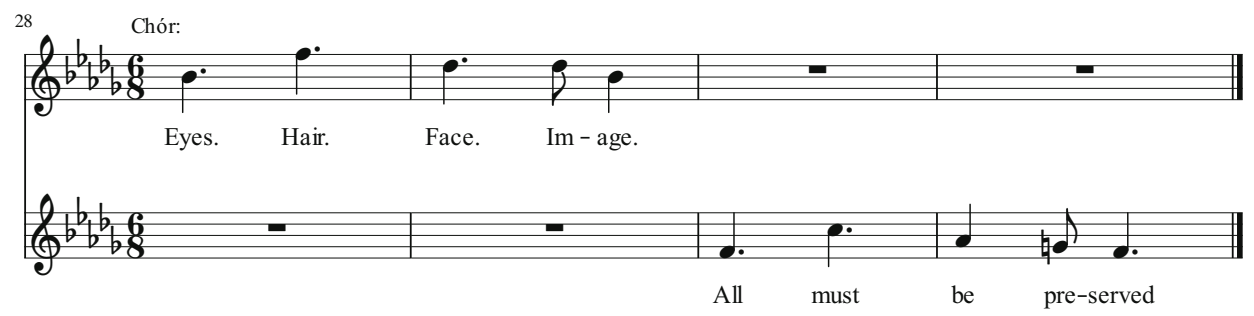

Początkowy fragment tekstu („Eyes, Hair, Face, Image” ze sceny Rainbow High) zostaje zachowany, lecz w jego zakończeniu pojawiają się słowa „all must be preserved” („wszystko musi zostać zakonserwowane”). Warto zauważyć, że omawianym motywem kompozytor posługuje się na zasadzie pewnej wyrazowej „symetrii”. Motyw ten bowiem ma postać minorową w skrajnych partiach Evity (wstępna uwertura oraz scena finału aktu II), w scenie środkowej natomiast (akt II) - utrzymany w trybie durowym - symbolizuje życie.

Kolejny motyw przypominający można nazwać „motywem złości”. Pojawia się on po raz pierwszy w finale aktu I Evity:
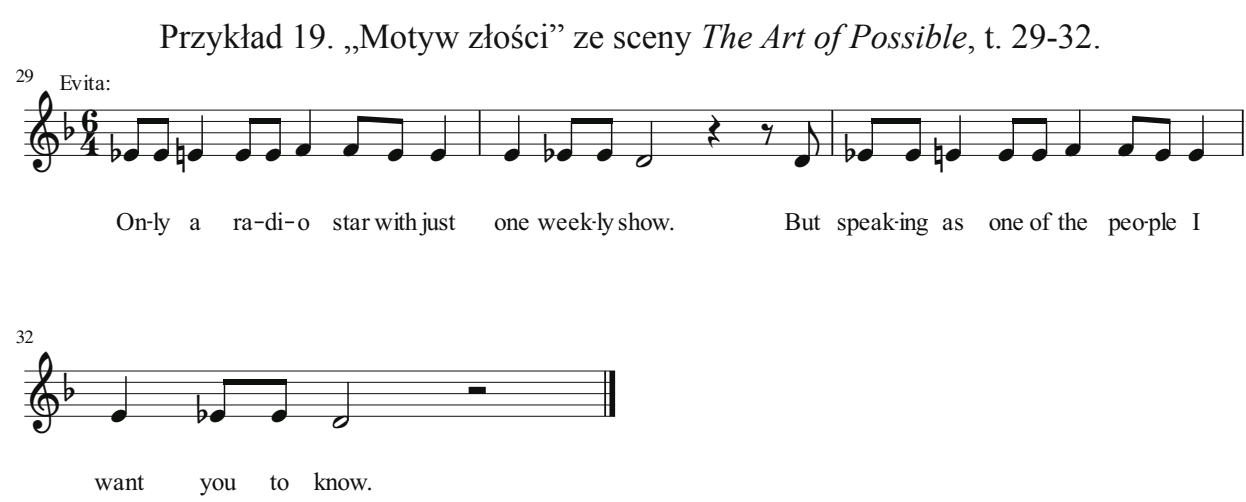

W scenie tej dochodzi do dialogu pomiędzy Evą a zbuntowaną ludnością. Bohaterka, w pełnej wściekłości scenie (płomienna przemowa na temat reżimu), przekonuje ludzi do poparcia Peróna. „Motyw złości” - użyty w scenie Raibow High - ukazuje również irytację Evity wobec swoich stylistów, których pomysły nie bardzo jej odpowiadają. Zostaje wykorzystany także w scenie The Art of Possible, gdy Evita, mówiąc w imieniu ludu, wyraża swoją złość na władzę w Argentynie, która nie jest w stanie zaoferować ludziom tego, na co zasługują. 
Istotnym motywem występującym w Rainbow High jest także ,,motyw podróży". Po raz pierwszy pojawia się on w scenie Buenos Aires, kiedy Evita przybywa do miasta:

Przykład 20. „Motyw podróży” ze sceny Buenos Aires, t. 1-5.
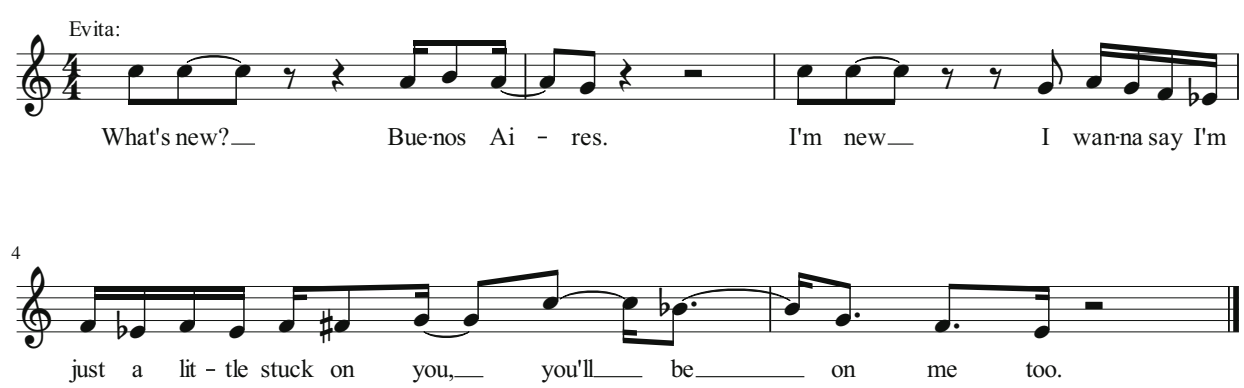

W scenie Rainbow High wykorzystany jest natomiast w ostatnim ogniwie, gdy bohaterka udaje się w podróż do Europy.

Ostatnim ważnym motywem przypominającym jest wspólny motyw miłosny Evity oraz Juana Peróna:

Przykład 21. „Motyw miłości” ze sceny The New Argentina, t. 9-12.
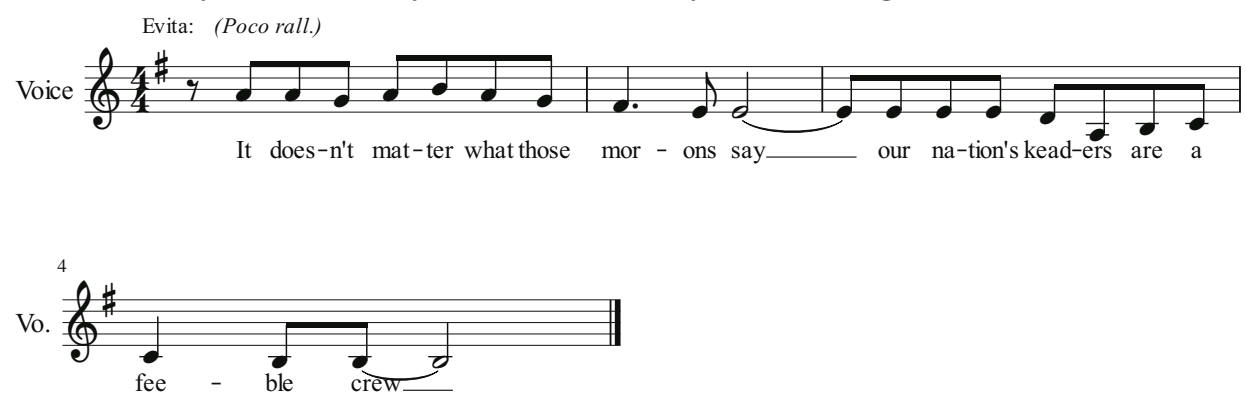

Pojawia się on w scenie finałowej aktu I, kiedy Evita jedzie wraz z Perónem do aresztu. Występuje on także w partii Peróna, który stwierdza, że Evita jest największym atutem rządu Argentyny, co ma miejsce w scenie She's a Diamond. Po raz ostatni motyw ów pojawia się w scenie Dice are Rolling, w chwili, gdy Perón śpiewa umierającej Evicie.

Wśród motywów przypominających w Evicie wymienić warto jeszcze kilka innych, które są mniej istotne z punktu widzenia formy i treści dzieła, lecz sposób ich wykorzystania wydaje się bardzo precyzyjny. Jednym z nich jest ,motyw zagubienia", który po raz pierwszy pojawia się w scenie Another Suitcase in 
Another Hall. Towarzyszy zdarzeniu, kiedy to Evita po raz pierwszy pojawia się w domu Juana Peróna, z którego wyrzuca jego poprzednią kochankę:

Przykład 22. „Motyw zagubienia” ze sceny Another Suitcase from Another Hall, t. 26-29.
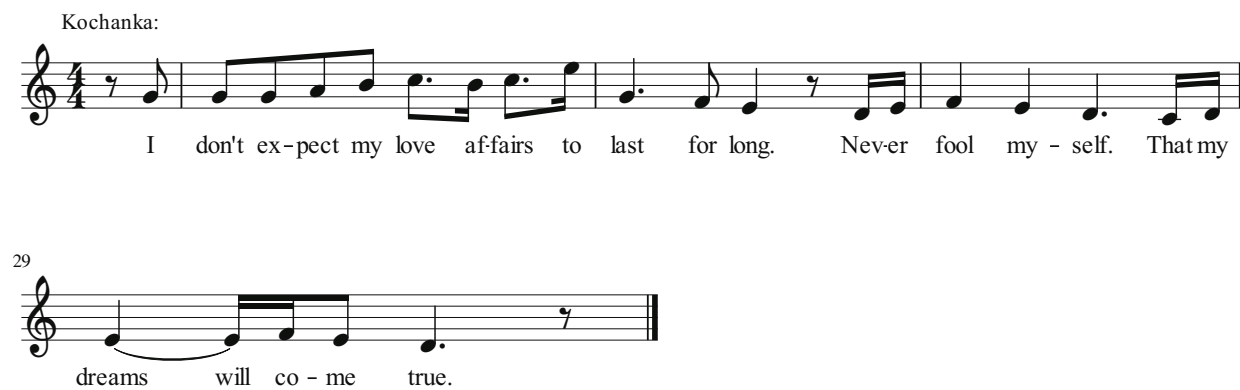

Motyw ten powraca w scenie The Actress Hasn't Learned, gdy Evita podkreśla, że nie pasuje do świata arystokracji. Po raz ostatni zostaje natomiast ukazany w przedostatniej scenie Dice Are Rolling, kiedy Evita umiera. Wówczas zostaje rozdzielony na dwie części. Pierwszą z nich śpiewa Juan, drugą bohaterka.

W Evicie pojawia się jeszcze „motyw cynizmu”. Przejmują go różni bohaterowie. Na przykład Magaldi w scenie Eva and Magaldi / Eva Beware of the City używa go w momencie, gdy postanawia odrzucić kochankę. Nie robi tego jednak wprost, lecz próbuje ją zbyć oszustwem:

Przykład 23. „Motyw cynizmu” ze sceny Eva and Magaldi / Eva Beware of the City, t. 143-152.
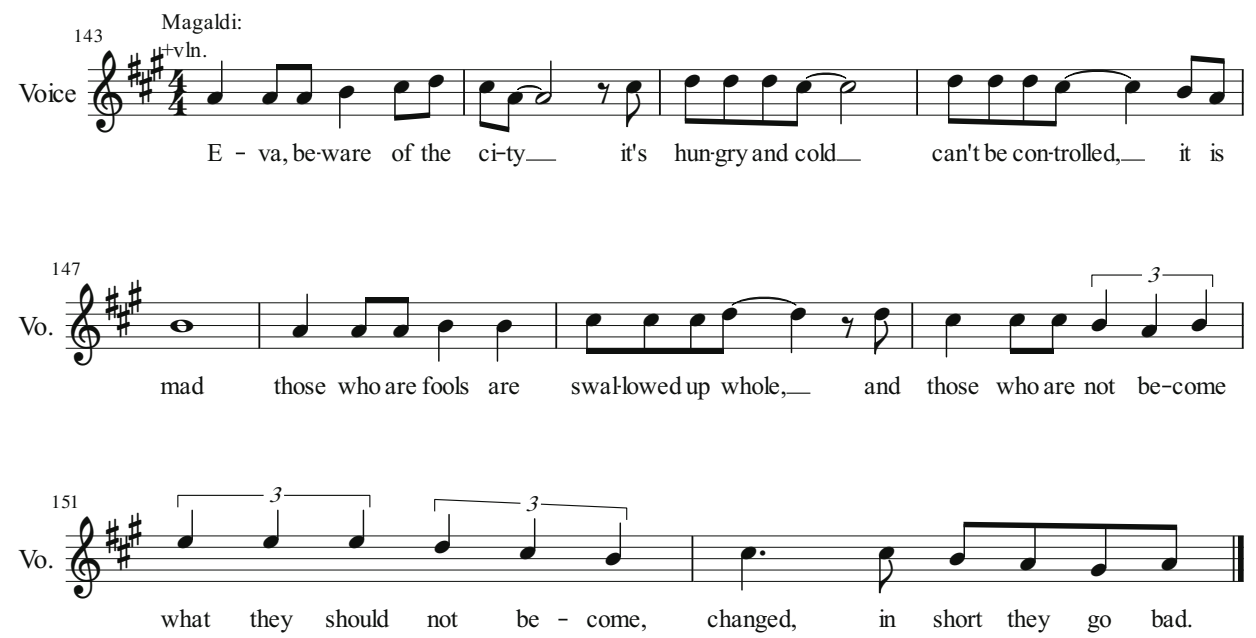
W scenie Goodbye and Thank You „motyw cynizmu” jest natomiast wykonywany przez Ché, który żegna każdego z wykorzystanych kochanków. Pojawia się jeszcze w scenie Dice Are Rolling, kiedy Evita śpiewa o tym, że nawet w obliczu choroby nie poddaje się.

Motywy przypominające w Evicie spełniają dużo ważniejszą i głębszą rolę niż w jakimkolwiek innym dziele Andrew Lloyda Webbera. Pojawiają się powiem nie tylko w warstwie ,powierzchniowej” utworu, lecz tworzą jego strukturę „głęboką", konstytuując wręcz cały idiom kompozytorski. Głębokie zespolenie muzyki z tekstem jest nie tylko zabiegiem pozwalającym słuchaczom odnaleźć się w przebiegu utworu, ukazuje również emocje, którymi targani są bohaterzy. Co równie istotne, motywy przypominające wpływają na architektonikę utworu - kompozytor dostosowuje budowę scen do konkretnych motywów, a nowy materiał melodyczny wprowadza tylko w nielicznych scenach (m.in. And the Money Kept Rolling In (and Out), High Flying Adore, You Must Love Me). Integrujące działanie motywów ilustruje przedostatnia scena musicalu, Montage, w której pojawiają się istotne motywy oraz partie mające symbolizować życie przemijające przed oczami bohaterki:

Przykład 24. Motywy przypominające wykorzystane w scenie Montage:

„I motyw Evity”, t. 2-10, „motyw cynizmu”, t. 12-13, „motyw miłości”, t. 23-31.
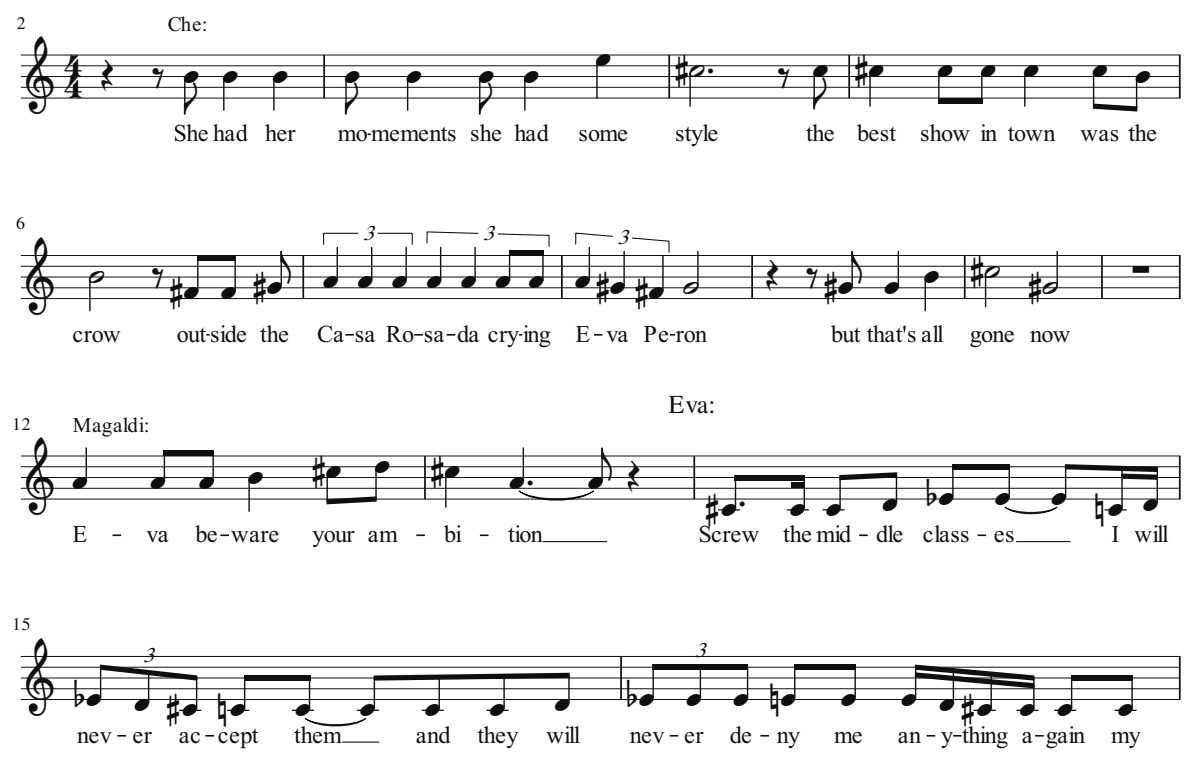

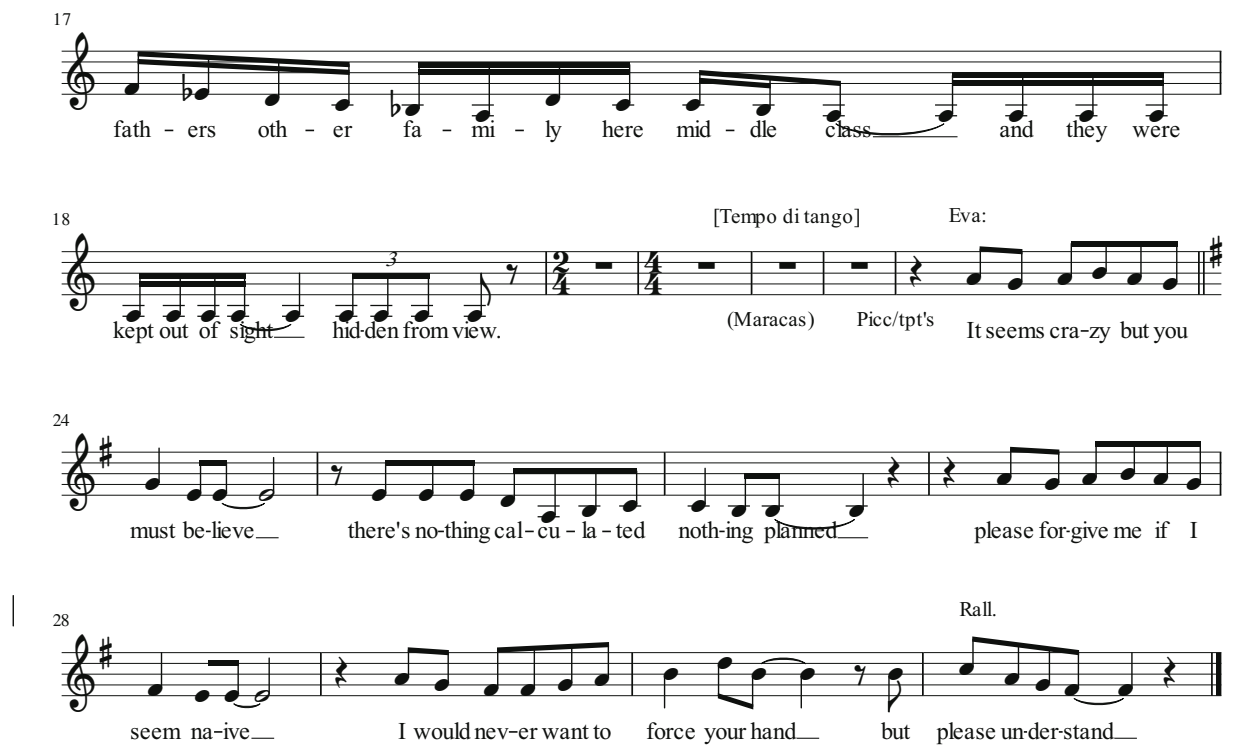

Scena ma duże znaczenie nie tylko ze względu na treść dzieła, lecz także jako swoiste podsumowanie środków kompozytorskich wykorzystanych w utworze. Nawet na podstawie tego jednego fragmentu, w którym poszczególne motywy skumulowane są jak w soczewce, daje się stwierdzić, że Lloyd Webber w sposób bardzo przemyślany wspomniane motywy wykorzystywał w przebiegu całego swego dzieła.

Technika motywów przypominających stosowana przez Lloyda Webbera ponownie przywołuje tradycje opery heroicznej i twórczość takich kompozytorów, jak Meyerbeer, Halévy czy Auber. W ich dziełach o cztero- i pięcioaktowej budowie zastosowanie motywów przypominających miało nie tylko cel pragmatyczny (umożliwiał odnalezienie się wśród licznych wątków), lecz także formalny, pozwalały one bowiem osiągnąć większą spójność dzieła. Podobne zabiegi integrujące stosowali kompozytorzy musicali w XX wieku (m.in. Gershwin, Kern, Berlin), ale Lloyd Webber rozwinął je szczególnie. Należy podkreślić fakt, że w czasach powstawania Evity taki sposób kształtowania zwartości stylistycznej dzieł musicalowych nie był typowy. W latach siedemdziesiątych XX wieku dominował charakter ,piosenkowy”, budowany na podstawie poszczególnych songów w konkretnym stylu (jak np. rockowe The Rocky Horror Show i Tommy, soulowo-bluesowy Dreamgirls czy rewiowy Cabaret). Pod tym względem Evita znacznie wyłamuje się poza ówczesną konwencję panującą w teatrach w Stanach Zjednoczonych i Wielkiej Brytanii. 


\section{Podsumowanie}

Przedstawiona analiza pokazuje, że Evita Andrew Lloyda Webbera jest dziełem syntetyzującym w sobie wiele różnorodnych zjawisk muzycznych. Zawiera elementy charakterystyczne nie tylko dla musicalu, lecz także dla innych gatunków scenicznych XIX i XX wieku. Pod względem architektonicznym ujawnia wpływy operetki, opery heroicznej i dramatu muzycznego. Klasyczna dla formy musicalu jest budowa aktów Evity, jednakże ich wewnętrzna struktura nie posiada już musicalowego charakteru. Duże bloki sceniczne są bowiem nietypową formą wyrazu dla twórczości kompozytorów działających na Broadwayu i West Endzie. Sceny finałowe w Evicie przypominają bardziej dzieła kompozytorów francuskich epoki romantyzmu, aniżeli kompozycje autorów amerykańskich i brytyjskich XX wieku. Twórczość XX-wieczna dla scen rozrywkowych opierała się bowiem na formie złożonej z odrębnych pieśni, a sytuacje, w których kompozytorzy budowaliby większe konstrukcje dramatyczne występowały rzadko; większość scen była wobec siebie odrębna i miała indywidualny charakter.

Wewnętrzne powiązania formalne występujące w Evicie wykazują silne związki ze sposobem kształtowania XIX-wiecznej opery heroicznej, w której następowało regularne budowanie napięcia poprzez płynne przechodzenie pomiędzy scenami. Szczególną sytuacją jest w przypadku opisywanego dzieła finał aktu I, który objętościowo i strukturalnie stanowi najbardziej skomplikowany element Evity. To z kolei może przywodzić na myśl późne finały z oper Mozarta (takie, jak finał aktu II Don Giovanniego czy finał aktu I Cosi fan tutte), które pozostawiły swój ślad w operze XIX wieku.

W Evicie Andrew Lloyd Webber obficie korzysta z form i gatunków, które ukształtowały się w muzyce klasycznej. Najbardziej charakterystycznym elementem jest zastosowanie cabaletty zaraz po uwerturze, co tworzy kolejne nawiązanie do romantycznej opery heroicznej oraz opery włoskiej (np. cabaletty Or dovo fuggio io mai... z Purytanów Vincenzo Belliniego czy Oh mio rimorso z Traviaty Giuseppe Verdiego). Pomimo istotnego wpływu czynnika musicalowego daje się zatem wyraźnie zaobserwować, że Webber inspirował się rozwiązaniami zaczerpniętymi z muzyki XIX stulecia. Także i stosowanie archaizacji wiąże jego dzieło z twórczością XIX-wieczną, w szczególności z dziełami takich twórców, jak Meyerbeer, Halévy. Chodzi tu na przykład o zastosowanie języka łacińskiego oraz użycie organów w scenie Oh, What a Circus? (podobnie jak w Hugonotach Mayerbeera czy Żydówce Halévy’ego). Pod względem rytmicznym Evita pozostaje pod bardzo różnymi wpływami. Zauważalne są odniesienia do operetki wiedeńskiej, opery heroicznej oraz muzyki latynoamerykańskiej, co ujawnia się szczególnie w zakresie wykorzystanych tańców. 
Ostatni współczynnik techniki kompozytorskiej Evity, jakim są motywy przypominające, jest już wyraźnie powiązany z grand opéra. Świadome użycie takich motywów i na tak wielką skalę nie miało swojego odpowiednika ani w operetce, ani w gatunkach poprzedzających ukształtowanie się musicalu, ani też w gatunkach musicalowych. Należy stwierdzić, że pod tym względem Evita przypomina bardziej dzieło operowe.

Analiza innych dzieł kompozytora, takich jak Jesus Christ Superstar (1970), Koty (1980) czy Upiór w operze (1986), wykazuje, iż język muzyczny Andrew Lloyda Webbera wzbogacany był przez stosowanie elementów charakterystycznych dla wcześniejszych form i gatunków scenicznych w sposób systematyczny. Wykorzystanie motywów przypominających w Evicie, później również w niewielkim stopniu w Kotach oraz w Upiorze w Operze, świadczy także o tym, że zjawisko zapoczątkowane w Jesus Christ Superstar było dla kompozytora bardzo istotne i stanowiło wyróżnik stylu indywidualnego. Istotnym dziełem z tego punktu widzenia staje się Upiór w operze, który poza tym, że skupia w sobie wszystkie najważniejsze elementy techniki kompozytorskiej Webbera, zawiera również elementy, których brakowało w poprzednich dziełach. Wykorzystanie klasycznego śpiewu operowego oraz instrumentacji rodem z neoromantycznego poematu symfonicznego wskazuje nie tylko na znajomość zasad aranżacji, lecz także na umiejętność swobodnego poruszania się w różnych stylistykach. Miały na to zapewne wpływ zarówno wykształcenie muzyczne Andrew Lloyda Webbera, jak i jego rozmaite doświadczenia muzyczne.

Marek Bielacki zwrócił uwagę, że

„[...] musical okazał się miejscem prawdziwej «korespondencji sztuk» - obszarem ich wzajemnego przenikania się i uzupełniania. Choć był w dużej mierze wytworem tzw. kultury masowej, popularnej, to jednak jego konkretne egzemplifikacje świadczyły o dość wysublimowanej estetyce tej właśnie formy dramatu muzycznego"16.

Evita stanowi bardzo wyrafinowany przykład takiego „przenikania się” i „uzupełniania”, różniący się jednak od dzieł komponowanych przez innych twórców w tych samych latach. „Kultowe” musicale, jak Hair Galta MacDermota, Cabaret Johna Kandera, Tommy zespołu The Who i Rocky Horror Show Richarda O'Briena, nawiązujące do pewnych pojedynczych zjawisk muzycznych i ideowych z przestrzeni kulturowej XX wieku (kontrkultura, muzyka kabaretowa, hard rock czy queer), są w swej strukturze muzycznej i literackiej dość hermetyczne. Wysublimowanie tych konkretnych paradygmatów estetycznych

\footnotetext{
${ }^{16}$ Bielacki, op. cit., s. 169.
} 
opiera się w nich głównie na pogłębieniu poszczególnych elementów, swoistym „uartystycznieniu” pop music. Kompozytorzy owych utworów nie nawiązywali do historycznych form wyrazu, tkwili w formie stworzonej na przełomie lat czterdziestych i pięćdziesiątych, przekształcając tylko treść swych utworów zgodnie $\mathrm{z}$ tendencjami współczesności. Webberowi natomiast udało się zintegrować to, co było najważniejsze zarówno w kulturze popularnej, jak i wysokiej czasów poprzedzających jego działalność. Evita jest dziełem syntetyzującym twórczość sceniczną XIX i XX wieku, jej komiczne oraz dramatyczne odsłony, łączącym różne, często odlegle estetyki. Co najważniejsze - jest dziełem posiadającym spójną myśl dramatyczną, pokazującym zarazem, że kody kulturowe o różnej proweniencji można zespolić w artystyczną całość.

\section{SUMMARY}

The analytical study of Andrew Lloyd Webber's musical Evita contains inter alia the description of the libretto, and the analysis of architectural-formal, rhythmical, and melodic features and stylization devices. In architectural terms, Evita shows the influences of operetta, heroic opera, and musical drama (e.g. in large integrated blocks of scenes, and characteristic final scenes). In the internal formal relations in the piece, the links with the nineteenth-century heroic opera are observable. Regarding the use of form, the composers utilizes those that appeared in Romantic Italian and French operas, while the stylization devices present in the piece have their reference to the nineteenth-century operatic forms in France and operetta compositions. An important structural element of Evita is reminiscence motifs referring inter alia to grand opera. The conscious use of these motifs on such a large scale that have no equivalents in operetta or in the genres preceding the emergence of musical, and in other musicals, causes Evita to be closer to opera in its motivic concept. Owing to the exceptional musical language combining tradition and the present, Webber's work is an example that the musical as a form of sublime entertainment can also satisfy the requirements of high art. 